\title{
"That Indefinite Area of Toleration": Criminal Conspiracy and Trade Unions in Ontario, 1837-77
}

Eric Tucker

Osgoode Hall Law School of York University, etucker@osgoode.yorku.ca

Source Publication:

Labour/Le Travail. Volume 27 (1991), p. 15-54.

Follow this and additional works at: https://digitalcommons.osgoode.yorku.ca/scholarly_works c) (1) $\Theta(9$

This work is licensed under a Creative Commons Attribution-Noncommercial-No Derivative Works 4.0 License.

\section{Recommended Citation}

Tucker, Eric. "'That Indefinite Area of Toleration": Criminal Conspiracy and Trade Unions in Ontario, 1837-77." Labour/Le Travail 27 (1991): 15-54.

This Article is brought to you for free and open access by the Faculty Scholarship at Osgoode Digital Commons. It has been accepted for inclusion in Articles \& Book Chapters by an authorized administrator of Osgoode Digital Commons. 


\title{
ARTICLES
}

\section{"That Indefinite Area of Toleration":}

\author{
Criminal Conspiracy and Trade Unions in \\ Ontario, 1837-77
}

\section{Eric Tucker}

\begin{abstract}
ALTHOUGHTHECURRENT generation of Canadian labour historians has extensively researched and written about the period of the first industrial revolution (roughly $1850-1900$ ), they have, on the whole, paid relatively little attention to the development and role of labour law, including the legal regime under which trade unions formed and operated. Rather, their focus has been on the social history of the working class. More recently, social historians and legal scholars have become interested in understanding the social role of law, focusing attention on its genesis, as well as its coercive and ideological functions. These developments have prepered the way for the revival of studies in the history of labour law. This research secks to understand how working-class experience, ideology, and activity, as revealed by the new social historians, both shaped and were shaped by law. The present paper aims to contribute to this new literature.
\end{abstract}

${ }^{1}$ From E.P. Thompeon, The Making of the English Working Class (New York 1963), 508. ${ }^{2}$ For a sample of the new Canadian labour history, sce Bryan D. Palmer, A Culture in Conflict (Montreal 1979) and Working-Class Experience (Toronto 1983) and Gregory S. Kealey, Toronto Workers Respond to Capitalion 1867-1892 (Toronto 1980). E.P. Thompson inspired both the new labour history and the social history of law. See his Making, and his Whigs and Hunters: The Origin of the Black Act (New York 1975). For other work that has followed Thompeon in making law a central focus of social history, see Douglas Hay et al. Abion's Fatal Tree: Crime and Society in Eighteenth Century England (New York 1975)

Eric Tucker, "That Indefinite Area of Toleration: Criminal Conspiracy and Trade Unions in Ontario, 1837-77," Labour/Le Travail, 27 (Spring 1991), 15-54. 
Its particular focus is the legal status of trade unions in Ontario, and the use of the criminal law to regulate union activities from the early 19th century to $1877 .^{3}$ Although the general criminal law and the law of master and servant (which made it a criminal offence for workers to breach their employment contracts) both played a role in this regard, it was the law of criminal conspiracy which most directly determined the legality of trade unions and their activities. Generally speaking, this body of law restricted the activities of groups of people, either because their purpose was unlawful, or because the means adopted to achieve an otherwise-lawful purpose were unlawful. The definition of unlawful purposes and conduct obviously was crucial, and its development in common law and statute will be examined here in some detail.

Historically, trade unions performed a variety of functions, some of which attracted more attention than others. For example, in so far as trade unions operated as benevolent societies, they were socially tolerated and largely unregulated by the state. Trade unions also acted as political and social agents dedicated to the reform or abolition of capitalist relations of production. However, within the context

and Francis Snyder and Douglas Hay, eds., Labour, Law and Crime: An Historical Perspective (London 1987). In their introductory essay, "Comparicons in the Social History of Law: Labour and Crime," ibid, 1, Snyder and Hay begin with the claim. "Law has almost invariably played a central role in the formation, reproduction, and discipline of wage workers and of the working class." In Canada, Paul Craven has played a major role in focusing attention on the role of labour law beginning with his "The Law of Master and Servant in Mid-Nineteenth-Century Ontario," in David Flaherty, ed., Essays in the History of Canadian Law, Vol. 1 (Toronto 1981), 175-211. Also see R. W. Kostal, "Legal Justice, Social Justice: An Incursion into the Social History of Work-Related Accident Lew in Ontario, 1860-86," Law and History Review, 6 (1988), 1-24. For a recent historiographic review which also calls for more careful examination of the role of law and legal ideology in shaping the Canadian working class, see Greg Marquis, "Doing Justice to 'British Justice': Law, Ideology and Canadian Historiography," in W. Wesley Pue and Barry Wright, eds., Canadian Perspectives on Low \& Society: Issues in Low and History (Otwawa 1988), 55-7. A resurgence of interest in the role of labour law history is taking place in the United States. For a useful survey of this rapidly expanding literature, see Wythe Holt, "The New American Labor Law History," Labor History, 30 (1989), 275. Also see William E. Forbath, "The Shaping of the American Labor Movement," Harvard Law Review, 102 (1989), 1109-256 and Christopher Tomlins, "Of the Old Time Entombed': The Resurrection of the American Working Class and the Emerging Critique of American Industrial Relations," Industrial Relations Law Journal, 10 (1988), 426-44 for discussions of these developments and extensive citation of the literature.

'The courts' civil law jurisdiction to award damages and issue injunctions was not developed in relation to labour-capital conflicts until the beginning of the 20th century. For in examination of its early development, see Jacob Finkelman, "The Law of Picketing in Canada: II," University of Toronto Law Jownal, 2 (1936-7), 344-60.

Indeed, they were forced to operate outside the common law because the courts would not protect their property or enforce their contracts. 
explored in this study, trade unions were not insurrectionary, and their broader objectives were pursued either through normal political channels, which did not expose them to legal liability, or through the kinds of actions they took in the labour market as economic agents. As labour market organizations, trade unions quintessentially were combinations of warkers whose purpose was to raise wages and improve work conditions. The achievement of these objectives required concerted activity to reduce competition between waters by such means as establishing a common selling-price or limiting entry through restrictive apprenticeship requirements. Success depended on the ability of trade unions to enforce their rules against employers and other workers, thus generating both inter- and intra-class conflicts. To win a strike, for example, it was nor enough for the current employees to withdraw their labour in concert other workers had to be prevented from taking their places. Various means were used to build and maintain union, craft, and class solidarity, including peer pressure, peaceful picketing, boycotting. as well as different degrees and forms of physical interference. Trade union power was directly at stake in the way unlawful conduct was defined.

Before turning to the study itself, two themes explored in this peper will be introduced. The first relates to the social nature of legal processes. It is important to recognize that law is not a monolithic body of formal rules produced by a unified institutional structure. Formal law is made by legislatures through statutes and by judges through their interpretation of statutes and their development of the common law. These decision makers do not necessarily act in concert and this is one reason why the formal law, in any given area and at any given time, is not necessarily fixed and certain. As well, law is not generated in a vacuum. Normally, there are "competing and conflicting socially constituted visions of legal order" which may find partial expression in the formal legal system itself, or which may undermine efforts to enforce formal rules which one social class seeks to impose on another. Thus, not only is law institutionally complex, it is also composed of both formal and informal rules and practices which may not be internally consistent with each other, reflecting the fact that, at times, law is "an arena of class struggle, within which alternative notions of law [are] fought out." One way of trying to illuminate these complexities in the area of trade union organization and activity is by distinguishing between a "legal zone of toleration" defined by formal legal rules and institutions, and a "social zone of toleration" which is more broadly and ambiguously defined by the practices and beliefs of different social groups.' By examining both what was happening in each zone and the interactions between them, we can deepen our understanding of the social history of 19-century labour law.

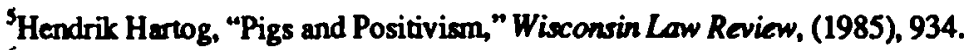

"E.P. Thompson, The Poverty of Theory (London 1978), 288.

'For a similar approach, see Axel Adlercreutz, "The Rise and Development of the Collective Agreement," Scandinavian Studies in Law, 2 (1958), 13. 


\section{LABOUR/LE TRAVAIL}

A second theme that will be addressed is the development of industrial legality." There is a broadly shared view that the history of the legal regulation of trade unions can be told as a story of the shift from repression to toleration. According to this perspective, during the early period of the development of capitalism, the law adopted a repressive strategy in response to worker combinations. However, as capitalist relations of production took root and matured, trade unions were accommodated in law, culminating in legislated collective-bargaining systems.' While it is true that industrial relations were legalized, the accuracy of the linear repression-to-toleration hypothesis obscures a far more complex pattern of repression and toleration which is revealed by a closer examination of the legal and social zones of toleration and their intersection. ${ }^{10}$ In particular, we will examine the early struggles of workers in Upper Canada and later Ontario which shaped, and were shaped by the system of industrial legality that was created.

\section{Criminal Combinations and Trade Unions in Upper Canada: 1800-1850}

ANY DISCUSSION OF LEGAL REGULATION of trade unions in Upper Canada during the first half of the 19th century must start by acknowledging that the process of working-class formation was in its earliest stages. State officials and mercantile elites concemed with challenges to their authority and to public order during the period from 1800-1837 did not see the primary threat coming from organized workers. Rather, the focus of attention was on the reformers and their supporters composed of both yeomen and 'mechanics. "11 Riotous conduct by canallers and other resource workers was not uncommon, but often it was triggered by religious and communal differences which were inflamed by harsh labour market conditions. The state's response to disorder or its threat was largely repressive. Leading dissidents were prosecuted and rioters faced a military or police response. ${ }^{12}$

The term was coined by Antonio Gramsci. For a discussion, see Frank R. Annunziato, "Gramsci's Theory of Trade Unionism," Rethinking Marxism, 1 (1988), 142-64.

'See A.W.R. Carrothers et al., Collective Bargaining Law in Canada, 2d ed. (Toronto 1986), John V. Orth "The Legal Status of English Trade Unions, 1799-1871," in Alan Harding, ed., Law-Making and Law-Makers in British History (London 1980), 195-207 and Antoine Jacobs, "Collective Self-Regulation," in Bob Hepple, ed., The Making of Labour Law in Europe (London 1986), 193-241.

${ }^{10}$ For a parallel critique of the conventional wisdom surrounding the emergence of statutory wllective bargaining during World War II, see Judy Fudge "Voluntarism, Compulsion and the 'Transformation' of Canadian Labour Law During World War II," in Gregory S. Kealey and Greg Patmore, ods., Canadian and A ustralian Labour History (Sydney 1990), 81-100. Also, see Ian McKay, The Craft Transformed (Halifax 1985), 81-113.

"Palmer, Working-Class Experience, 50.

${ }^{12}$ On the conflicts between the Family Compact and various reformers, and the repressive responses, see Barry Wright, "Law, State and Dissent in Upper Canada, 1804-1838," D.Jur. Thesis, York University, 1989. On the riotous conduct of canallers and other "rough" segments of the working class, see Palmer, Working Class Experience, 35-9 and Appendix 
Strikes during this period were less frequent. Bryan Palmer has identified only 23 in all of Canada between 1800 and 1837 . Of these, 10 occurred in Ontario. Seven of these strikes involved skilled warkers who were likely to have been members of proto-trade unions, while the others were conducted by canallers who were more likely to be organized in ethnocultural societies. Twenty-eight strikes were conducted in Canada between 1838-1849, but only three of these occurred in Ontario. Clearly, trade unions during this early period were mostly small, local organizations which led a fragile existence and did not seriously threaten the structure of existing employment relationships. ${ }^{13}$

Although Pentland's assertion that "'labour' and the 'labour problem, 'in their modem connotations, had not been thought of before $1837^{\text {mit }}$ is clearly overstated. it gains some support from an event probably unknown to him. That year, for the first time, workers in Upper Cansda were prosecuted for a criminal conspiracy arising out of a trade dispute. ${ }^{\text {15 }}$ The charges arcese cut of a conflict between John Counter, then a master baker, and his journeymen bakers in Kingston. Kingston was, at the time, a growing commercial and administrative centre which also contained a budding manufacturing sector. ${ }^{16}$ John Counter was an aggressive entrepreneur who, starting from the family's bakery, became a prominent local businessman and politician, serving as mayor for eight terms in the 1840s and $1850 \mathrm{~s} .{ }^{17}$ His competitive approach to business was exemplified in his bakery when,

II. Also see H. Clare Pentland, Labour and Copital in Canada, 1650-1860 (Toronto 1982), 188-99, and Ruth Bleasdale, "Class Conflict on the Canals of Upper Canada in the 1840's," in Michael S. Cross and Gregory S. Kealey, eds., Pre-Industrial Canada 1760-1849 (Tononto 1982), 100-38. On the need to bring ethric and religious identities into class analysis, see Gregory S. Kealey, "Orangemen and the Corporation," in Victor L. Russell, ed., Forging a Consensus (Toronto 1984), 41-86.

${ }^{13} \mathrm{See}$ Bryan D. Palmer. "Labour Protest and Organization in Nineteenth Century Canada. 1820-1890," Labowr/Le Travaih 20 (1987), 61-83; Eugene Forsey, Trade Unions in Canada 1812-1902 (Toronto 1982), 16-31; Desmond Morton with Teny Copp, Working People (Ottawa 1984), 9-16; Charles Lipton. The Trade Union Movement of Canada 1827-1959 (Toronto 1973), 1-25 and H.A. Logan, Trade Unions in Canada (Toronto 1948), 23-8.

${ }^{14}$ H.C. Pentland, "The Lechine Strike of 1843," Canadian Historical Review, 29 (1948), 256.

${ }^{15}$ Conspiracy charges had been laid earlier in Quebec arising out of a strike of hatters in 1815. See Palmer, Working-Class Experience, Appendix I.

${ }^{16}$ On the development of the economy and class relations, see Bryan D. Palmer, "Kingston Mechanics and the Rise of the Penitentiary, 1833-1836," Histoire Sociale/Social History, 13 (1980), 7-32; and Parricia E. Malcolmson, "The Poor in Kingston, 1815-1850," in Gerald Tulchinsky, ed., To Preserve and Defend (Montreal 1976), $281-97$.

${ }^{17}$ Margaret Angus, "John Counter," Historic Kingston 27 (1979), 16-25, which is an extended version of the entry on Counter she wrote for Dictionary of Canadian Biography, Vol. IX (Toronto 1976), 162-3. (Hereafter DCB) For more on Counter's various activities, see Palmer, "Kingston Mechanics," 31; Brian S. Osborne and Donald Swainson, Kingston: Building on the Past (Westport, Ont. 1988), 98-109 and various references in Tulchinsky, 
in late 1836, he lowered his prices below those being charged by other local bakers." One way he was able to undencut his competitors was by paying his men lower wages. In late January 1837 , a delegation of six journeymen bakers led by Thomas Palmer, Counter's foreman, presented the master with a paper they had signed stating they would not work unless wages were increased. Counter refused to accede to their demands, notwithstanding that another bakery in Kingston had agreed to pay higher wages. All of the men struck, except for Palmer. Counter hired replacements and the striking bakers endeavoured to "seduce these men from their work. ${ }^{\text {n' }}$ On 4 February, six strikers were summoned before three magistrates and charged with acts of combination and, possibly, intimidation. ${ }^{20}$ They were all bound over to appear at the upcoming Quarter Sessions.

The Court of Quarter Sessions convened on 26 April. John S. Cartwright, Esq., was elected to preside over the Bench of Magistrates. In his opening address to the Grand Jury, Cartwright previewed the important matters coming before them. With respect to the journeymen bakers he noted:

You will in the course of your inquiries be called upon to investigate a charge of Conspiracy arising from the combination of journeymen to increase their wages. This[,] gentlemen[,] is a grave offence, which is punished by law. A conspiracy of this nature is defined to be "An agreement between two or more persons to effect a legal purpose with a criminal intent, or by improper means," to which may be added conspiracies or combinations by joumeymen to raise their wages.

The following day the six defendants were arraigned and pleaded not guilty. Twelve jurors were sworn and a trial was conducted. Three witnesses testified on behalf of the prosecution, including John Counter and his foreman, John Palmer, who had betrayed his co-workers. Three witnesses were called for the defence." According to the British Whig, the evidence "ought to have procured a conviction but the jury thought otherwise. ${ }^{n 3}$ The accused were acquitted.

ed., To Preserve and Defend. Neither the strike nor the prosecution are referred to in any of the above.

${ }^{11}$ Upper Canada Herald (Kingston), 6 December 1836.

${ }^{19}$ British Whig (Kingston), 10 February 1837.

${ }^{20}$ The only reference to a charge of intimidation comes from the report in the Britisth Whig, 10 February 1837. Every other account, including a subsequent account of the trial in the British Whig, 1 May 1837, just referred to a combination or conspiracy to nise wages. The records of the Quarter Sessions indicate that the defendents were chargod with conspiracy. See Kingston Quarter Sessions, Minutes, 27 April 1837. Onturio Archives (hereafter OA). RG 22, Series 54, Vol. 4.

${ }^{2}$ Chronicle \& Gazetie (Kingston), 26 April 1837, Upper Canada Herald, 2 May 1837. J.S. Cartwright was a prominent local lawyer, banker and conservative member of the Legislative Assembly. See DCB, Vol. VII, (Toronto 1988) 156-60.

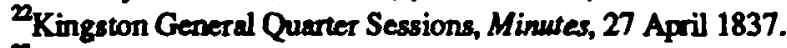

25 British Whig, 1 May 1837. 
The case provides an excellent starting point for our discussion, as it raises difficult problems regarding the legal and social zones of toleration, and their interactions. With regard to the legal rules governing wotker combinations, analysis must begin with the reception of English law into Upper Canada. ${ }^{2}$ English criminal law was in force in Upper Canada by virtue of the Quebec Act of 1774 and a reception statute passed by the Parliament of Upper Canada in 1800 fixing the date of reception of English criminal statues at 17 September $1792 .^{20}$ English criminal statutes passed after that date did not become part of the law of Upper Canada unless enacted locally or specifically made applicable by the Imperial Parliament. The reception date, however, was not the bright line it seems at first. English common law, both criminal and civil, was continuously received in Upper Canada until full legal independence was established. Moreover, English laws both criminal and civil, and common and statutory, were only received to the extent they were suited to the circumstances of the colony. Thus, English criminal statutes enacted prior to the reception date might not apply in Upper Canada, while common law rules developed after the reception date could. With respect to civil law, the Upper Canada Parliament received the law of England as it stood on 15 October $1792^{2}$, subject to the same qualifications that applied to the criminal law.

What, then, was the legal starting point in Upper Canada with respect to trade unions and their activities? First, we must consider what English legislation was in force in Upper Canada in 1837. Clearly, English criminal kgislation enscted after 1792, including the general Combination Acts of 1799 and $1800^{27}$ which made it illegal for workers to make agreements between themselves for the purpose of raising wages or altering conditions of employment, was not in force. Nor, for that matter, were the repealing acts which granted trade unions some limited immunity from prosecution for criminal conspiracy while also regulating their activities.

This leaves the more difficult question of the status of the pre-1792 English statutes. There was a long history of state-imposed restrictions on combinations of workers in England. The earliest legislation can be understood as an attempt to protect the integrity of the statutory wage-fixing system first adopted in the aftermath of the Black Death. Because it was forbidden to agree to alter administratively fixed wages or conditions of labour, combinations formed for this purpose

${ }^{24}$ On reception generally, see Sir Kenneth Roberts-Wray, Commornealth and Colonial Law (New York 1966), 532-79 and J.E. Cote, "The Reception of English Law," Alberta Law Review, 15 (1977), 29-92.

${ }^{25} 14$ Geo. 3 (1774) c. 83 (UK) and S.U.C. 1800, c. 1.

${ }^{26}$ S.U.C. 1793, c. 1 .

$2_{39}$ Geo. 3 (1799) c. 81 (UK), repealed and replnced by 40 Geo. 3 (1800) c. 60 (UK).

${ }^{25} 5 \mathrm{Geo} .4$ (1824) c. 95 (UK) and 6 Geo. 4 (1825) c. 129 (UK). For a general introduction to the English statutes, see M.A. Hickling, Citrine's Trade Union Law, 3d ed (London 1967), 4-6 and Orth, "The Legal Status of English Trade Unions, 1799-1871." For the broader background, see Alan Fox, History and Heritage (London 1985), 68-125 and John Rule, The Labouring Classes in Early Industrial England, 1750-1850 (London 1986), 255-309. 
involved agreements to breach a statute. This was an unlawful purpose, and was subject to criminal sanctions both at common law and under statutes which were passed from 1360 onwards prohibiting such combinations. However, most of the combination acts were enacted in the 18th century in response to disputes which developed in particular trades and in particular locations. ${ }^{2}$ Typically these statutes voided all contracts for raising wages or reducing hours, and exposed workers who combined for this purpose to criminal sanctions.

Were any of these statutes in force in Upper Canada? Paul Craven examined this question with respect to master and servant law and found that the situation was unclear. Some authorities assumed that at least parts of the omnibus Elizabethan employment statute and the 18th-century combination acts were in force, but superior court decisions beginning in the 1830 s began to cast doubt on this view. None of the cases cited by Craven dealt with those aspects of the legislation which established wage-fixing and prohibited combinations to alter wages. ${ }^{30}$ Yet, in a subsequent article on the subject of workers' conspiracies, Craven asserts, without qualification (or legal citation), that Canadian judges had declared the ancient statutes not to be in force. ${ }^{31}$ This is an overstatement which is neither supported by the reported case law, nor by Craven's earlier study. The formal legal status of the older English statutes in Upper Canada was not resolved by 1837 nor, as we shall see, was it subsequently determined by the superior courts. Nevertheless, we can clarify the possible legal positions that could have been maintained at the time.

As a matter of law, older English wage-fixing legislation that was geographically specific clearly would not apply in Upper Canada. Those statutes which regulated wages for specific trades without geographic limitation conceivably could have been held to be generally applicable, but nevertheless inoperative in Ontario because of their incompatibility with local circumstances. Indeed, it presumably was because of their incompatibility, and because administrative wage-fixing legislation was on the decline in England, that no attempt was made to apply unrepealed English wage-fixing legislation in Upper Canada, or to enact local wage-fixing legislation. ${ }^{32}$ However, there were also statutory prohibitions on combinations by various groups of workers and at least one commentator, W.C. Keele, in his Provincial Justice, an Upper Canadian magistrate's manual first published in 1835, cited a 16th-century statute prohibiting combinations of artifi-

${ }^{20}$ For an overview of the early English employment laws, see W.E. Minchinton, ed., Wage Regulation in Pre-Industrial England (New York 1972). Also see John V. Orth "English Combination Acts of the Eighteenth Century," Law and History Review, 5 (1987), 177-94 for an extensive examination of these carly acts.

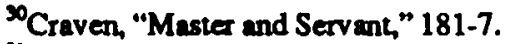

${ }^{31}$ Paul Craven, "Workers' Conspiracies in Toronto," LabourlLe Travail, 14 (1984), 60.

${ }^{32}$ Wage-fixing legislation was passed in Nova Scotin in 1777 but only remained in force for one year. See Charles Bruce Fergusson. The Labowr Movement in Nova Scotia Before Confederation(Halifax 1964), 9 and Bryce M.Stew art, Canadian Labor Laws and the Treary (New York 1968), 116-7. 
cers, wartmen, and labouress formed to alter wages as if it applied in Upper Canada." Although Chief Justice Robinson's comments on the inapplicability of the Stature of Artificers in Shea v. Choat, a master and servent case, suggest that Keele's view might not have been upheld had the question come before the courts, we cannot be certain of this, because Robinson specifically left open the possibility that "a clause here and there might be carried into effect in this colony, oc anywhere, from the general nature of their provisions. ${ }^{\text {nht }}$ Thus, even if we can assume that early wage-fixing legislation was not in force in Upper Canada, the legal status of the prohibitions passed in support of that system were far from clear. Moreover, unlike master and servant law, uncentrinties about the applicability of English combination statutes did not lead to the enactment of local legislation." Although we can speculate that it was unlikely that the older English stetwes prohibiting combinations of workers would have been held to be in force, the question was not authoritatively resolved.

This leaves us with the common law. During a regime of administrative wage-fixing, combinations to raise wages were criminal a common law because their purpose was in breach of statutc. However, as that regime doclined in England, and never existed in Upper Canada, the common-law basis for criminalizing worker combinations needed to be reconceptualized. Could workers lawfully combine for the purpose of altering wages and working conditions in a more or less "free" labour market? Upper Canada inherited an ambiguous legacy from the English courts. Older case-law arose in the context of the wage-fixing system, while newer case-law arose in the context of legislation enacted after 1792. Moreover, the cases that came before the courts did not usually raise the question of a trade union's legality in stark form. Usually, events other than the simple act of combination gave rise to the proceedings, whether under statute or common law. As a result, ambiguities in the law remained unresolved. Analysis is further clouded by the multiple and conflicting interpretations that subsequent commentators placed on the early cases. For lawyers, legal history is not an academic concern, but a legal tool. There were significant pay-offs for the lawyer who could convince contemporary decision-makers to characterize carlier interpretations of the law as mis-

${ }^{33}$ W.C. Keele, The Provincial Justice (Toronto 1835), 488. The statute in question was 2 \& 3 Edw. 6 (1548) c. 15 (UK). Keele's position remained unchanged in the fifth edition of his manual published in 1864.

${ }^{34}$ Shea v. Choot (1846), 2 UCQB 211 at 221.

${ }^{33}$ Craven, "Master and Servant." Master and Servant Act, S. Prov. Can. 1847, c. 23. Only Nova Scotia enacted legislation modelled on the Combination Act of 1800 prohibiting workers from combining to raise wages [S.N.S. 1816, c. 27]. The Act was repealed by R.S.N.S. 1851, c. 170. On the background to this legislation, see Pergusson, Labour Movement, 13-4. There was repressive legislation in Ontario but, for the ressons mentioned earlier, it was not directed against combinations of workers. In particular, see the Seditious Meetings Act, S.U.C. 1818, c. 11 repealed by S.U.C. 1820, c. 4. For discussion see Wrighth, "Law. State and Dissent." 


\section{LABOUR/LE TRAVAIL}

takes. Another way to put the point is that the law and its history were, and are, intensely political and, therefore, not surprisingly, contentious, contested, and confusing.

There were a number of reported 18th-century English cases, beginning with $R$. v. Journeymen-Taylors of Cambridge, which suggested that combining for the purpose of raising wages was a crime at common law independent of the existence of wage-fixing legislation. ${ }^{3}$ In addition to the reported cases, C.R. Dobson identified an additional 28 prosecutions in which common-law conspiracy indictments were brought against workers in labour disputes in the 18th century. The precise grounds which supported the indictments are not always clear from Dobson's descriptions, but at least in some cases the act of combining to increase wages formed at least part of the charge. Moreover, it appears that by the end of the 18th century, many people believed that all workers' combinations were criminal conspiracies. For example, Orth points out that the master millwrights who petitioned Parliament for a combination law for their trade assumed that at common law, the combination was illegal. The problem, in their view, was the delay and

${ }^{36} \mathrm{~A}$ good example of this is the debate between jurists in the late-19th century over the "correct" interpretation of the earlier common law cases on the legality of trade unions. These were not just academic arguments; rather, they were used to advance legal and political programs. R.S. Wright, The Law of Criminal Conspiracies and Agreements (London 1873), took the view that workers' combinations as such were not criminal. He was actively involved with the Trade Union Congress' Parliamentary Committee from 1872 and assisted in drafting the Conspiracy and Protection of Property Act and the Employers and Workmen Act which were passed in 1874. See M.L. Friedland, "R.S. Wright's Model Criminal Code: A Forgotten Chapter in the History of the Criminal Law," Oxford Journal of Legal Studies, 1(1981), 322. Sir James Fizjames Stephen, A History of the Crininal Law of England, Vol. 3 (London 1883), 202-11, agreod with Wright. He was linked with the reform tradition of Benthamite utilitarianism. See generally K.J.M. Smith, Jomes Fitzjames Stephen (Cambridge 1988). The opposite view was taken by Sir William Erte, The Law Relating to Trade Unions (London 1869). He was a more traditional lawyer who, at the time he published this work, was in his mid-seventies and had recently retired as the Chief Justice of the Court of Common Pleas. See Dictionary of National Biography, Vol. VI, 810-1.

${ }^{37}(1721), 8 \mathrm{Mod}$. 10, where is was held (at 12) that the failure to plead the beach of statute was not material because "it is a conspiracy which is an offence at common law." In $R$. v. Eccles (1783), 1 Leach 275 the cour upheld the conviction of seven defendants for conspiring to impoverish a tailor by the name of Booth and to prevent him from carrying on his trade. Lord Mansfield held (at 276-7) that it was unnecessary to specify the means to be used because the "illegal combination is the git [sic] of the offence." He went on to say, "so every man may work at what price he pleases, but a combination not to work under certain prices is an indictable offence." The defendants were sentenced to six months' imprisonment. A similar view was expressed in dictum by Grose J. in R. v. Mawbey (1796), 6 T.R. 619 at 636 and by Lond Kenyon in R. v. Hammond (1799), 2 Esp. 719.

${ }^{30}$ C.R. Dobson, Masters and Jowrneymen: A Prehistory of Industrial Relations 1717-1800 (London 1980), 126-39. 
expense involved in enforcing the common law." These cases did not, however, establish a clear, uncontestable common-law position. For example, Blackstone, writing in 1769, only referred to statutes and not to the common law in support of the proposition that combinations by artificers to raise the price of labour were unlawful conspiracies. ${ }^{\circ}$ Nevertheless, the cases certainly suggested that the boundaries of common law conspiracy were sufficiently ambiguous that lawyers and judges at the time could plausibly assert, when it suited them, that simple combinations to raise wages were crimes at common law.

Judges and lawyers in Upper Canada had to look beck to 18 th-century cases for guidance, because much of the 19-th century English case law was decided on the basis of the Combination Acts of 1799 and 1800 and the repeal measures of 1824 and 1825 . These cases provided Keele with support for the view that combinations to raise wages were criminal conspiracies independent of statute. In his book, The Provincial Justice, he cited both the Cambridge Tailor's case and Blackstone's Commentarles for the proposition that it was a criminal conspiracy for two or more workmen to enter into an agreement not to wort unless for certain wages." J.S. Cartwright, the presiding magistrate in the Kingston journeymen bakers' conspiracy trial, also believed combinations by journeymen to increase wages were criminal conspiracies, although his address to the jury did not make it clear whether his view was based on the common law or the applicability of English legislation. Clearly, however, this position was contestable, either on the grounds that trade unions as such were not criminal conspiracies under English common law, or that local conditions were sufficiently different to justify the courts' not following these precedents. Neither Keele's nor Cartwright's views were binding on judges, and there were no authoritative Canadian judgments one way or another. As a result, the legal status of trade unions as labour market organizations remained unresolved.

Finally, what was the significance of the jury's refusal to convict the Kingston journeymen? It does not reveal much about the formal law, even though in theory juries are supposed to apply the law according to instructions given by the judge because, in practice, juries often followed their own view of the justice of the case. In that sense, the jury verdict might reflect a social zone of toleration that was different from the legal zone described by the presiding magistrate. However, we should be careful not to assume that there was a social consensus on this question. Presumably, the journeymen bakers saw nothing wrong, legally or otherwise, with

\footnotetext{
${ }^{39}$ See speech from (1798-99) 54 Commons Joumal 405 cited in John V. Orth "English Combination Acts," at 195. Also, see John V. Orth, "The English Combination Laws Reconsidered" in Snyder and Hay, eds., Labour, Law and Crime, 138.

"William Blackstone, Commentaries on the Laws of England, Vol IV (1769), 159.

${ }^{41}$ Keele, Provincial Justice, "Conspiracy" at 124 and "Workmen" at 488. The reference to Blackstone is obscure and may refer not to the original text, but rather to notes that were made in various editions to update the text.
} 
combining to reduce wage competition. There is no indication they conducted their activities clandestinely. Moreover, Counter's price-cutting activities had caused other bakers some constemation, perhaps becsuse they believed that customary price-fixing within the community was perfectly legitimate. This toleration may have extended to combinations of workers since, prior to 1837 , no employer attempted to challenge the legality of this behaviour. There was, however, another view in the community. Counter, along with others, clearly believed in the virtues of free competition in all markets, including the labour market. "The absence of legal actions prior to 1837 could be attributed to the fact that trade unions were of recent origin in Kingston and that relations between masters and men were still characterized by a high level of mutuality, despite the outbreaks of antagonism." Inter- and intra-class conflicts over the social zone of toleration took on a legal form only when Counter attempted to mobilize the law's coercive authority in support of his vision. However, the refusal of the jury to convict suggests a limit on the ability of a segment of the local elite to dominate the legal order and make it serve its interests exclusively. Conflict in the social zone carried over to, and fostered uncertainty in, the formal law and its operation."

Although developments in the 1840 s did little to clarify the formal legal position of trade unions, they revealed increasing conflict within and between zones of toleration. So far, we know of only one other attempt to invoke conspiracy laws against a trade union in Upper Canada prior to 1850, and this also occurred in Kingston. Some time in 1841, the community's joumeymen tailors formed a society, one of whose objects was to fix a schedule of prices and regulations for work in the industry. Later that year, an agreement was reached between the society and the master tailors of Kingston. However, a number of master tailors who had signed the agreement subsequently ceased to abide by it, and the joumeymen's society responded by publishing a handbill or placard which was posted through

\footnotetext{
"Counter's price-cutting was defended on the basis of the benefits it brought to the poor and to the prosperity of the town. Upper Canada Herald, 6 December 1836. A letter to the Chronicle and Gazette, 19 April 1837, signed "Anti-Conspiracy" condemned s combination of fishermen for limiting quantity and fixing price.

"Palmer, "Kingeston Mechenics," 22-8.

4It is interesting to note that recent discussions of Americen conspiracy law emphesize its indeterminate character and point to the rocial conflicts which contributed to this state of affairs. See Sean Wilentz. "Conspiracy, Power and the Eerly Labor Movement: The People v. James Melvin ef al, 1811," Labor History, 24 (1983), 572-9; Christopher L. Tomlins, "Criminal Conspiracy and Early Labor Combination: Mnssechusetts, 1824-1840," Labour History, 28 (1987), 370-85. Also see Wythe Holt, "Labour Conspiracy Caes in the United States, 1805-1842: Biss and Legitimation in Common Law Adjudication, Osgoode Hall Law Jownal 22 (1984), 591-663 and Raymond L. Hoglex, "Law, Ideology, and Incustrial Diecipline: The Conspiracy Doctrine and the Rise of the Factary Syatem, "Dickinson Law Review, 91 (1987), 697-745, both of whom concede that the law was indeterminate, but who claim that it was manipulated by the judiciary to reach paticular results.
} 
the town. The placard announced the fact that certain named tailos were not conforming to the list, and wamed members of the society not to work for these employers. Ross Dodd was one of the master trilors who refused to abide by the list. He obtained indictments against three society members - James Thompson, William Noden and David Dranan - for conspiracy to injure himself and other master tailors. The case was tried before Judge Macaulay J. at the Midland District Assizes towards the end of May, 1842. J.S. Cartwright, the presiding magistrate in the journeymen bakers' case, acted for the prosecution.

Cartwright's strategy was to show that worker combinations threatened the public peace and drove up the price of clothing. In his opening address to the jury, Cartwright spoke of the evil caused by such combinations, citing murders which had been committed by members of the Glasgow couton spinners union and the silk weavers of Lyons, France who had two or three times caused the city to be placed in a state of siege. He also told the jury of conversations he had with an old master tailor who reported that prices had risen a hundred times since 1808. Mr. Dodd, two other master tailors and two journeymen employed by Dodd testified for the prosecution. They gave evidence that they were threatened by members of the society and that they were likely to be injured in their trade because the wages being demanded were higher than those of other mechanics in Kingston and of other tailors in the region. Neither the newspeper sccounts nor Macanlay's benchbooks indicate that any defence witnesses were called or even that a defence submission was made to the jury. The jury found Thompson and Noden guilty, fined them five pounds each and held them to keep the peace for one year. Dranan was acquitted. The Kingston Herald ended its account of the proceedings with the waming, "Mechanics should know that such combinations are illegal."

The case is interesting in a number of respects. None of the accounts of the case clearly indicate the substance of the conspiracy charge, but it appears that it was framed as a conspiracy to injure or to coence and not simply as a combination to raise wages. The newspaper's broader assertion about the illegality of combinations as such was not supported by the case as reported. Yet the fact that this employer did not simply allege a conspiracy to raise wages does not prove that trade unions as such were lawful. In England between 1800 and 1824, trade unions clearly were unlawful associations, but they were not prosecuted on this basis. ${ }^{46}$ Similarly, one cannot conclude that trade unions were legal because the tailors'

\footnotetext{
${ }^{1}$ Kingston Herald, 31 May 1842. The other sources on the trial are the Kingston Chronicle and Gazette, 28 May 1842, Macaulay, Benchbooks, OA, R.G. 22, Series 390, Box 6, Env. 1, 247-54 and Court of King's Bench, Assize Minutebook-Criminal-1838-42, OA, RG 22, Series 134, Vol. 7, 547, 550, 552.

${ }^{46}$ In addition to the fect that workers were not prosecured simply for combining, it also seems prosecutions in general under the Combination Acts were infrequent. See Orth. "The English Combination Laws Reconsidered," and E.P. Thompeon, Making, 503-10.
} 
society operated openly. Trade unions in England operated openly and grew between 1800 to 1824, despite the Combination Act"

The behaviour of the trade union and the legal strategy of the employer are probably more indicative of the conditions of social toleration than of the law's formal content. Early toleration of trade unions by most employers was rooted in a social formation in which cultural, social, and ideological bonds sustained a reasonably high level of mutuality between the 'producing classes.' Moreover, because trade unionism was most common among the most skilled and respectable segment of the working class, it was not surprising that early trade unionists emphasized their mutual interests with employers and promoted and defended the respectability of their craft, in part by policing the conduct of their members. Dinners organized by unions honouring employers were common and reflected and strengthened bonds of solidarity. Certainly, there were outbreaks of conflict, but the paternal dimensions of class relations clearly played a mediating role in shaping the employer's view of trade unions. ${ }^{43}$ Compared to ethnoreligious organizations like the Orange Order and the 'rough' navvies on the canals, trade unionists were not as likely to pose a significant threat to public order."

The zone of social toleration clearly influenced decisions about when and how to use the law. So long as worker combinations did not attempt to impose their will on employers or other workers by means that were independently unlawful, it was unlikely that legal action would be taken. Juries would be unlikely to convict, even if they ought to have according to the formal law. Moreover, there was little need to press the point because the incentive for an employer to use the law would be greatest during a time of conflict, and it was during conflicts that unlawful means were most likely to be used, given their rather broad definition. Further, the general

47Thompson, Making, 503.

${ }^{48} F$ For example, section 4 of the Constitution of TTU Local 91 provided, "The object of this Union shall be to promote, by every lawful means, the interests of the employers as well as of the employed; the encouragement of good workmen, and the use of every means which may tend to the elevation of Printers in the scale of social life...". More generally, see Palmer, A Culture, ch. 4; Paul Craven and Tom Traves, "Dimensions of Paternalism: Discipline and Culture in Canadian Railway Operations in the 1850s," in Craig Heron and Roben Storey, eds., On the Job: Confronting the Labour Process in Canada (Kingston 1986), 47.

4he difference in the level of concern was reflected in the focus of legislation enacted during this period. In the aftermath of the Canal disturbances, a law was passed authorizing the Government to proclaim that, in a locality where public works were being carried on, no person employed on those works could be in possession of firearms. See S. Prov. Can. 1845, c. 6. It is also interesting to note that in 1843, the Legislative Assembly passed a bill for the discouragement of Secret Societies. It was reserved for Her Majesty's pleasure and assent was withheld the following year. Trade unions or combinations of workers were not mentioned as a concern in the debates. Rather, it was aimed at the Orange Order and other similar groups. See Debates of the Legislative Assembly of United Canada (1843), 497-511 and (1844), 427; and Kealey, "Orangemen." 
criminal law and the master and servant statures could often provide the legal basis for prosecution. Use of these laws might have been particularly attractive becsuse unlike conspiracy charges, prosecutions could be conducted before magistrates without juries, thereby limiting the influence of popular ideas of tolerable conduct upon the output of the legal system.

The social zone of toleration clearly had its limits, even if they were disputed. The invocation of the image of trade unions as a hazard to public order and the economy by the prosecution served the function of drawing the jury's attention to such limits and of convincing it to define them more restrictively. It undermined and narrowed the legitimacy of trade union activity by portraying the interests of unionized workers as being opposed to those of the community over a broad range of issues, including higher wages. In that regard, the law's major function was not coencive but ideological. Even in its unclear state, the law cast shadows on the legitimacy of trade unions, and reminded everyone involved that legal and social toleration was contingent on trade unions behaving 'responsibly' both with regard to the ends they pursued and the means they used.

To illuminate further the diversity of views regarding both the formal legal and the social position of unions, it is also worth examining the responses to the conflicts on the Lachine and Beauhamois canals in $1843 .^{\text {II }}$ The Boend of Works in its report to the Legislative Assembly for that year made a number of general comments about the proper role of the state in labour relations. The report rejected completely the idea that the state should become involved in regulating wage rates. This was a matter "to be regulated solely by the ordinary principles of supply and demand." In the event of labour disputes, "the only interference on the part of the authorities of the country, which is necessary and called for in such cases, is merely to protect, effectually, those disposed to work at the wages offered from others, who, by violence and intimidation, endeavour to prevent them." Of course, the definition of intimidation could restrict union activity quite substantially. In this

\footnotetext{
so The ideological function of legal pronouncements in American labour conspiracy cases of this period is emphasized in Hogler, "Law, Ideology, and Industrial Discipline." It should also be noted that in 1841 the first legislature of the United Canada paseed four stututes consolidating and amending the criminal law. One of those statutes related to offences against the person, S. Prov. Can. 1841, c. 27, and was modelled on an English act, 9 Geo. 4, c. 31 (1828). Section 35 of the Canadian act (25 of the English) punishod asenults "committed in pursuance of any conspiracy to raise the rate of wagea," while section 36. (26 Eng.) punishod assaults on seamen for the purpose of hindering them from worting at their trade. There is no evidence that these specific provisions were enacted in response to local events.

${ }^{51}$ Although the events took place in Lower Canda, it was during the Union period when Upper and Lower Canada were governed by a common legislature. Moreover, English criminal law applied in Lower Canada by virtue of the Quebec Act and, therefore, in the absence of local legislation, was the same as in Upper Canada.
} 
laissez-faire view, however, prohibitions against the existence of combinations were not seen as necessary so long as the individual's right to work was protected."

A somewhat different view was taken by Commissioners who were appointed to inquire into the canal disturbances. As a general matter, they seemed to favour a higher level of state involvement in labour relations. They criticized Mr. Laviolette, a stipendiary magistrate appointed to maintain order among the workmen on the canal, for his passivity. In their view, when discontent became manifest, he should have enquired into its origin and attempted to effect a settlement. More importantly, the Commissioners, one of whom (C. Wetherall) was a magistrate and another (Lewis T. Drummond) a lawyer, seem to have believed that combinations of workers to raise wages were unlawful. In criticizing Laviolette, they asserted that, "when, at length, a strike was contemplated as a means of redress, he should have pointed out the illegality of all combinations of that nature and the punishment reserved for all those who would dare to resort to such violations of the law."53

If we can summarize: at least until 1850, a number of officials and legal commentators believed that combinations of workers as such were unlawful. ${ }^{\text {st }}$ Nevertheless, there was a zone of social, political and possibly formal legal toleration, although this issue remained unresolved in the courts. ${ }^{35}$ Moreover, it did not seem that employers or, for that matter, workers had a particularly keen interest in mobilizing the law on behalf of their interests. The question of the legality of trade unions and their activities was not one that seems to have occupied a very large place in these early workers' struggles. This state of affairs may have been driven both by strategic considerations of the parties and by a diminished role for formal law in a social formation in which personal as opposed to economic and

52 Journals of the Legislative Assembly of the Province of Canada, Appendix "Q" (1843). English legislation prohibiting intimidation was so broadly interpreted by the judiciary that the legislature was moved on a number of occasions to narrow its definition. See, Hickling, Citrine's Trade Union Law, 7-10.

${ }^{53}$ Journals of the Legislative Assembly of the Province of Canada, Appendix 'T"' (1843).

Sh In addition to the whorities previously cited, also see Hugh Taylor, Manual of the Office, Duty and Liabilities of a Justice of the Peace (Montreal 1843), 128-9 for the view that combinations to raise wages were per se unlawful.

${ }^{55}$ The only other case during this period in which workers were charged for conspiracy arose out of a bitter and lengthy strike by journeymen shoemakers in Montreal in the spring of 1849 against the firm of Brown \& Childs. During the strike there were various incidents of violence for which individuals were prosecuted before the police courts. However, Brown \& Childs also decided to bring conspiracy charges against 22 members of the society. The precise grounds on which the conspiracy charges were based are not clear from the newspaper reports, and the shoemakers were soquitted by the jury. For sccounts of the trial, see Montreal Transcript and Commercial Advertiser, 27 and 30 October, 1849. The Pilot (Montreal,) 25, 27, and 30 October 1849 and Montreal Gazente, 29 and 30 October 1849. 
contractual relations still played a major role. Further research on this period is required, however, before firm conclusions can be drawn.

\section{Establishing the Zone of Formal Legal Toleration: 1850-1872}

THE MDCENTURY PERIOD is widely seen to mark the beginning of Canada's first industrial revolution, understood as both a tochnical and social transformation." Technologically, there was a rapid growth of railways and the development of machine production. Also, the labour process was being transformed as craftworkers faced challenges to their traditional work practices and to their control over labour markets. This led to a substantial growth in trade union organization during the early 1850s, and a strike wave in Canada from 1851 to 1855 during which there were as many strikes as there had been during the period 1815-1850." Skilled workers organized into trade unions were at the centre of these confrontations between labour and capital. Economic recessions led to declines both in unionization and strike activity during the lase 1850 s and early $1860 \mathrm{~s}$, but there was a resurgence in the late 1860 s and early 1870 s. Given these new conditions, how did the legal and social zones of toleration develop?

Paul Craven thonoughly examined the use of conspiracy laws in Toronto between 1854-1872." His article raises two important issues for labour-law historians. The first is his claim that although a number of judges, justices of the peace, and others made comments suggesting that combinations of workers to raise wages were illegal, a close reading suggests that they knew this was incorrect because it clearly had been established in law that trade unions were not criminal conspiracies before 1872. The second issue is the use of the law during trade disputes. Craven's

${ }^{56}$ As a general matter, marxist theorists have pointod to the importance of the legal form in cementing and legitimating impersonal class domination in capitalist societies. Law arguably was less importent in societies in which power wes exercised through personal relations of domination and servitude. See for example, Desel Sayer. The Violence of Abstraction (Oxford 1987), 105-10. However, it would be dengerous to epply this genaralization to the specific historical situation in Onterio during this period without correful study, especially given the rather heated debate on this issue. For exemple, compare G. Blaine Baker, "'So Elegant a Web': Providential Order and the Rule of Secular Law in Early Nineteenth Century Upper Canada," University of Toronto Law Journal, 38 (1988), 184-205; with Paul Romney, "Very Late Loyalist Fantasies: Nostalgic Tory 'History' and the Rule of Law in Upper Canada" in Pue and Wright, eds., Canodian Perspectives, 119-47.

${ }^{\top}$ Michael S. Cross and Gregory S. Kealey, ods., Canada's Age of Industry, 1849-1896 (Toronto 1982); Palmer, Working-Class Experience, chap. 2; Gregory S. Kealey, "The Structure of Canadian Working-Class History" in W.J.C. Cherwinski and Gregory S. Kealey. eds., Lectures in Canadian Labour and Working-Class History (St John's 1985), 25, and Craig Heron and Robert Storey, "On the Job in Canuda" in Heron and Storey, ods., On the Job, 7.

StPalmer, "Labour Protest," 67.

${ }^{\text {S9 }}$ Paul Craven, "Workers' Conspiracies." 
data suggests that although conspiracy charges may have been brought somewhat more frequendy during this period than in the preceding 50 years, their use was not widespread. Moreover, Craven emphasizes that in the eight cases he found, no one was committed for trial simply on a charge of conspiracy to raise wages in the absence of some other charge alleging unlawful means. This pattem, according to Craven, is evidence of, and is explained by, the formal legality of trade unions.

Craven has, I believe, overstated the degree to which a clear legal position on the legal status of trade unions emerged in Ontario ${ }^{\circ}$ prior to 1872. The English common law position became increasingly confused in the third quarter of the 19th century. Trade unions were protected by statutes granting them immunity, thereby implicitly assuming their liability to criminal prosecution at common law. Judicial comments on the scope of common law liability were usually obiter (incidental), and, moreover, reflected a diverse set of views."

Given the state of British jurisprudence, Canactian judges and commentators were forced to articulate the local law without reference to an authoritative English precedent. The magistrate's manuals published in Ontario during this period all expressed the view that trade unions formed for the purpose of regulating wages and other terms and conditions of employment were criminal conspiracies. ${ }^{62}$ There also were judicial comments expressing support for this view, even though, in the cases reviewed by Craven, no one was actually convicted simply for combining. For example, Police Magistrate Gumett expressed, on a number of occasions, the view that worker combinations were illegal, and the burden of Chief Justice Morrison's charge to a grand jury and its presentment in a case in 1871 was that combinations of workers to increase wages were, as a general matter, criminal conspiracies.

This leads us, then, to Robert Harrison's legal opinion given to George Brown in the context of the Toronto printers' strike in spring 1872 to the effect that it was unlawful for workers to combine for the purpose of raising wages. ${ }^{4}$ I would argue that Harrison's opinion put a construction on the law which it reasonably could bear. In this regard, Harrison was doing what any good lawyer would do for a client: he put forward the strongest case he could based on the available legal precedents. He cited at length the charge of the conservative English judge, Baron Bramwell,

DStrictly speaking, the proper designution from 1850 to 1867 wa Canada West but the populer designatioti remained Upper Canada. For rimplicity's suke, however, I will just refer to Ontario.

"John V. Orth, "The Law of Strikes, 1847-1871," in J.A. Guy and H.G. Beale, eds, Law and Social Change in British History (London 1984) 126-44 and Hickling, Citrine's Trade Union Low. 7-10.

W.C. Keele, The Provincial Justice (Toronto 1864), 181 and John McNab, The Magistrate's Manual (Toronto 1865), 183. McNab citad no wuthority for his view.

"Craver, "Workers' Conspiracies," 54-8.

CRobert Harrien was a prominent Toronto lawyer and a Conservative member of Parliament. His opinion, dated 27 March 1872, was published in the Globe, 30 March 1872. 
to the jury in $R$. v. Druitt, an English picketing case decided in 1867 , in which Bramwell elaborated upon fundamental right of the individual to be free from both coercion of the body and of the will. ${ }^{\text {.5 }}$ Although the case did not state that trade unions were criminal conspiracies at common law, it did articulate the broad, libertarian legal principles which, if accepted, weighed in favour of this position. Harrison then asserted the criminality of trade unions at common law, ${ }^{6}$ and cited 18th-century cases which supported this view. He then discussed the 19th-century English legislation and cases interpreting the range of trade union activity permissible under them.

The point here is not that Harrison's opinion was necessarily the "correct" or even the best legal view. Clearly, it could have been and was disputed at the time." The claim, then, is that the formal law was sufficiently ambiguous that competent lawyers, using accepted norms of legal reasoning, could construct arguments in support of diverse positions. Until there was an authoritative adjudication of these arguments, which there never was, there could be no correct position, only a range of legal possibilities. This view more accurately reflects the reality of the legal position prior to 1872 than does Craven's unqualified claim trade unions were not illegal.

How, then, can we explain the fact that no trade unionist was, as far as we know, convicted simply for the act of combining for the purpose of raising wages? The answer to this lies in the strategies adopted by employers in light of the totality of laws regulating trade unions and their conduct, the social zone of toleration, and the intersection of these considerations. Beginning with the legal zone, although the legality of the simple act of combining was not clearly established, other limits on workers' behaviour, individually and in combination, were. Under the local

\section{${ }^{60}(1867), 10$ Cox 592 at 523.}

${ }^{6}$ Harrison's original opinion letter to Brown has not been found. In the version published in the Globe, Harrison's assertion that trade unions are criminal conspiracies at common law is made to appear as if it were part of Bramwell's judgement. The source of this error and whether it was intentional are unknown.

${ }^{7}$ See letter by "Lex" in Leader, 2 April 1872. Also, it was asserted by Dr. Riddel in a speech at a rally in support of the printers that Thomas Moss, Harrison's law partner and a Liberal, would have offered a different opinion. Leader, 4 April 1872.

"As Craven notes, McNabb's decision to commit the printers to trial was based on a determination that there was a case to be tried and not on a definitive legal finding. Moreover. a police magistrate's decision on a question of law did not carry much authority in the judicial hierarchy. It is also interesting to note that $\mathrm{McNabb}$ was the brother-in-law of Archibald McKellar, a prominent Brownite and a quintessential machine politician. See Leader, 8 April 1872 and S.J.R. Noel, Patrons, Clients, Brokers (Toronto 1990), 214, 288.

In that regard, it is interesting to note that much of the criticism which followed the publication of Harrison's opinion accepted its validity and instead emphasized the injustice of the law he revesled. For example, see letters signed by "Anglo-Canadien" and John Hewitt in Leader, 1 and 2 April 1872. 


\section{LABOUR/LE TRAVAII}

Master and Servant Act, it was unlawful for workers to breach their individual contracts of employment, and to induce other workers to do the same. Offenders were liable to be fined or imprisoned after summary proceedings before a local magistrate. The extent to which these laws were used to restrict strike activity by workers in Ontario during this period requires further study, but there is evidence that on at least some occasions employers resorted to this strategy. ${ }^{\circ}$ Moreover, during the printers' strike, employers signed replacement workers to one year contracts, and prosecuted them under the master and servant legislation for desertion if they gave in to the strikers' blandishments or entreaties to leave. ${ }^{n}$ Although this law could only be used against workers whose employment could not be terminated on short notice, compared to the drawn-out and ultimately unsuccessful attempt to prosecute printers for conspiracy, the advantages of summary proceedings before the magistrate were obvious.

In addition to the master and servant statutes, there were other laws which could be relied upon to control the actions of striking workers. There were

${ }^{70}$ Greg Kealey's examination of the prosecution of workers in Toronto between 1867 and 1878 indicates that master and servant law was most heavily used during periods of high strike activity. He further documents how this legal strategy was pursued against the moulders' union during labour disputes in 1871. Kealey, Toronto Workers, 148-9, 68-70, Paul Craven is currently doing a full-scale study of the law of master and servant, and its use, throughout Canada in the 19th century. If practices in Ontario resembled those in England, then master and servant law would have been the primary mochanism of legal coercion against workers. For example, Gravener Henson and George White, $A$ Few Remarks on the State of the Laws at Present in Existence for Regulating Masters and Work People (1823), observed, "The Combination Act is nothing: it is the law which regards the finishing of work which masters employ to harass and keep down the wages of their workpeople." Douglas Hay has documented the use of master and servant law to break smaller strikes in the industrial midlands in late-18th and early-19th century England. Moreover, he has shown that the use of master and servant wholly dwarfed the use of the combination acts. See Douglas Hay, "Masters, Servants, Justices and Judges: The Law of Master and Servant in England in the Eighteenth and Nineteenth Centuries, "paper presented at the Commonwealth Institute, University of London, November 1988. Daphne Simon, "Master and Servant" in John Saville, ed. Democracy and the Labor Movement, (London 1954), 160, has shown that this practice persisted beyond 1850. Doug Hay is currently working on an extended study of master and servant law and its administration throughout this period, and with Paul Craven, a comparative project on master and servant statutes in the Commonwealth and Empire.

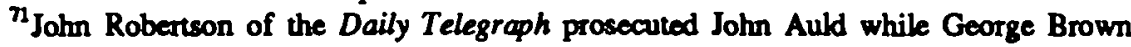
prosecuted Walter Couthard (or Cawthard), F. Merrick, and T. Flym. They were all tried before McNabb. Auld and Couthard were convicied. Auld was fined \$30 and Couthard S15. See Globe, 3, 4 and 24 April 1872. Merrick and Flymn had their cases remanded until the end of April and then did not appear for trial See Leader, S, 8 and 29 April 1872. McNabb's conduct of the Police Court and of Auld's case in particular was harahly criticized in an editorial entitled "Judicial Tyranny," Leader, 4 April 1872. 
numerous criminal offences relating to the protection of public order, private property, and the person which restricted the scope of permissible activity during a strike. In addition to such general provisions, there was a section of the criminal statutes dating from 1841 which provided that any person convicted of an assault "committed in pursuance of any conspiracy to mise the rate of wages" could be imprisoned for up to two years. ${ }^{2}$ This provision remained in force until 1869 , when Parliament passed legislation reforming and consolidating the criminal law statutes of the founding provinces. This statute was modeled on an 1861 British act relating to offences against the person, but adopted language from a Nova Scocia statute of 1864 which broadened the circumstances in which a person might be subject to harsher penalties for criminal actions committed in a trade conflict. ${ }^{\text {th }}$

Finally, employers who wished to prosecute for criminal conspiracy did not need to rely on the illegality of the purpose of combining to raise wages. They could rely on illegal means which would include breaching, or inducement to breach the master and servant laws or apprenticeship laws, the use of tureats, violence or intimidation to prevent others from working, or any interference with property rights. English judges had defined these terms so broadly that it was unclear whether even peaceful picketing was legal, let alone some of the other actions that were commonly pursued in support of trade union objectives. ${ }^{74}$ Only an ideologue like Brown, therefore, would raise the stakes by relying on the illegality of the purpose of the combination.

In sum, the formal law was less than clear on the legality of trade unions and simple strikes. Perhaps there was a zone of formal legal toleration; perhaps not. However, the law clearly prohibited most worker activity which went much beyond the simple act of combining and withdrawing labour in concert when it was not a breach of contract to do so.

Whatever the formal legal position, it seems that a social space for trade unions and strikes accompanied by peaceful persuasion was being recognized. Certainly, trade unionists never doubted their legitimacy and, according to Ostry, "trade union leaders appear to have assumed that their associations had the same validity as other analogous bodies in the community. ${ }^{\text {"75 }}$ Moreover, even as class-consciousness

\footnotetext{
${ }^{n}$ Above, note 50.

TIt provided that "Whosoever, in pursuance of any unlawful combination or conspiracy to raise the rate of wages...unlawfully assaults any person, or in pursuance of any such combination or conspiracy, uses any violence or threat of violence to any person, with a view to hinder him from working or being employed at such trade, business or manufacture is guilty of a misdemeanour" punishable by up to two year in prison, with or without hard labour. S.C. 1869, c. 20 s. 42. The italicized words were from the Nova Scotia act, S.N.S. 1864, c. 9 , which was probably enacted in response to the bitterly contested strike at the Sycney Mines that year.

${ }^{74}$ Orth. "The Law of Strikes."

75 Bemard Ostry, "Conservatives, Liberals and Labour in the 1870's," Canadian Historical Review, 41 (1960), 94.
} 
became more shapply defined and class relations more antagonistic from the 1850 s to the 1870 , attacks by cmployers on trade unions as such do not appear to have increased significantly. Employers may have resisted union efforts but, by and large, did not seek to have the state repress them. In at least this limited sense, there was a zone of toleration by employers.

There were, I think, a number of reasons why a frontal assault on trade unions was not attempted. Perhaps the most obvious reason was a practical one. The political, economic, and social costs of repressing trade unions and prohibiting all concerted activity by workers would have been 100 high. Trade unions were part of the industrial landscape, even if considered a nuisance, and removing them would not have been an easy task. In a sense, then, their presence had to be accepted as an inevitable outcome of industrialization. ${ }^{76}$ Repression would only force trade unions to become secret organizations, and "perhaps the terrors of the Internationale - would be sure to follow." Moreover, repression would have been a particularly perilous strategy to attempt in Ontario, given the province's dependence on the immigration of stilled labour from England where trade unions had already achieved a measure of legality. The deterrent effect on potential immigrants, as well as the perceived illegitimacy of subjecting Ontario workers to a more repressive legal regime than the one in England, were offered as justifications for the legislative response to the criminal prosecution of the striking printers in $1872 .^{7 n}$

One further practical problem which limited resort to the law was that any proceeding that involved a jury trial, such as a charge of criminal conspiracy, faced a very uncertain outcome regardless of the formal legal position. For example, in the same month that the Toronto printers were charged, nine employees of the Toronto lumber merchants Walsh \& Lovey were brought before McNabb (in his capacity as a County Justice) and charged with conspiracy arising from their occupation and shut-down of the firm's sawmill in King township. This action was in response to a dispute over the payment of wages. The men were committed to trial but were acquitted at Quarter Sessions despite uncontradicted evidence that they had damaged the shanty and physically prevented the mill from being operated." In effect, the jury interjected its view of the zone of toleration into the

\footnotetext{
${ }^{76}$ For example, see an editorial on trade unionism in the Mail, 10 April 1872. John Hewitt. a leader of the Coopers' Union, put the point more colourfully. "Trade unions are a product of the age... [In] tyying to trample Trades' Unionism out of existence here,...they might as well try to stem Niagara" Ontario Workman, 25 April 1872.

"Leader, 2 April 1872.

${ }^{7}$ See Debates of the House of Commons of Canada, 7 May 1872, (Macdonald). Also see the comments of A.W. Luder, MPP, in Ontario Workman, 18 April 1872.

"Sec Ontario Worbman, 25 April 1872; Leader, 25 and 26 April 1872; Globe, 26, 27 and 29 April, and 15 June, 1872; and YorkCounty Quarter Sessions, Minutes, OA, RG 22, Series 94, Volume 12, 416-9.
} 
operation of the kegal system, theneby limiting the ability of the judiciary to make operative its formal definitions of criminal conduct.

Another factor favouring the toleration of trade unions related to the restructuring of capital. As natural barriers to competition were eroded by improvements in the transportation system, manufacturers and merchants often responded by forming associations or combinations. ${ }^{\text {DO }}$ Courts indicated their consent to such combinations, provided they did not unreasonably restrain trade. "The acceptability of combinations of capital made it more difficult to insist that worters could not legitimately combine to protect their interests, provided of course that their behaviour remained within certain boundaries. This difficulty stemmed from changes in the conditions of legitimation in capitalist social formations. Maintaining the appearance of labour and capital's formal legal equality and of the state's neutrality between them increasingly was becoming a political, if not a legal, imperative as personal relations of comination and subordination gave way to impersonal market relations. Thus, when the claim that workers' combinations were criminal conspiracies was raised during the printers' strike of 1872, the Mail cautioned, "If the mere fact of woitsmen uniting to raise the rate of wages ought to continue to rank among our laws as a crime, a combination of employers to keep down wages would have to be placed in the same category... Justice has not two scales, one for labour and another for capital. ${ }^{\text {no }}$

As well, the shift from artisan to factory production entailed a concentration of lerger pools of capital and the assembly of a larger wortforce. The disparity between the individual worker and the employer was growing and becoming more obvious. Combination by workers seemed to be not only an inevitable, but also a reasonable response. For example, an editarial in the Upper Canada Law Journal commented. "The struggles between labour and capital have been of long duration. But inasmuch as capital is generally represented by the few who are powerful, and labour by the many who are without the power of wealth, co-operation, or combination on the part of the latter, has been found necessary.

Finally, there always were ambiguities in the political, moral and legal theory of the free market, and particularly the free labour market. Within the framework of general rules supporting private property and contract, individuals were free to

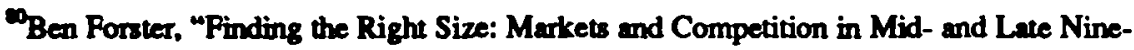
toenth Century Ontario," in Roger Hall et al. eds., Patterns of the Past (Toronto 1988), $150-73$.

"The Ontario Salt Co. v. The Merchants Salt Co. (1872), 18 Gr. 540.

"Mail, 25 April 1872. It is also interesting to note that both workers and employers pointed to Brown's active efforts to induce printers from outside Toronto to leave their employment to work for the Globe, and asked whether this activity violated the law according to Harrien's opinion. See letter from John Hewitt, Leader, 2 April 1872, and complainis from other mester printers in Leader, 9 and 27 April 1872.

"Upper Canada Law Journal (N.S.), 3 (1867), 57. 
compete, contract, and maximize their self-interest, taking advantage of whatever opportunities presented themselves. Yet, some if not most contracts reduced the market opportunities of others. Moreover, if one entity enjoyed great martet power, it could significantly reduce competition to the point that the market's operation was threatened. Because of these conflicts, the kind and degree of advantage-taking that is permissible could not be deduced from the abstract ideal of the free market. Some other reference point had to be found, whether in economics (efficiency), or, political and moral theory. It was not surprising, therefore, that contemporary commentators had difficulty articulating a clear and consistent view of the line between legitimate market conduct and unacceptable coencion. For example, the Mail, a conservative paper, took the view that, "[t] $t$ he moral right of workmen to combine for the purpose of getting the highest price for their labour is as clear as any right which freemen can exercise." But, it also supported limits on trade union activity. "Coercion is incompatible with the enjoyment of liberty; and whoever resorts to that forbidden weapon seeks to destroy the conditions on which his own liberty rests." Although the paper did not clearly identify when freedom of contract (combination) became coercion, it accepted that the simple act of combining to increase wages was moral, legitimate market behaviour which, in the paper's view, should also be made legal. ${ }^{85}$ Other employers and conservative commentators drew the line more narrowly. ${ }^{\circ}$

If we retum to the events surrounding the Toronto printers' strike, and particularly to the reaction to Harrison's opinion and Brown's prosecution, I would argue that the claim that worker combinations to raise wages were criminal conspiracies was not outrageous from a legal point of view, but rather became notorious because it asserted a position which was politically and socially untenable. Indeed, after Harrison's opinion was printed, John Hewith dared Brown to proceed on its basis, predicting that if he did, he "would raise a storm of indignation about his ears," and that "an intelligent public shall demand in language that cannot be misunderstood by our law makers, that these dead letters of the past shall disgrace our statute books no longer. ${ }^{n / 7}$ Moreover, I suspect Harrison knew that such a prosecution would be strategically misguided, even if technically possible. First, in his opinion letter, Harrison pointed to a number of purposes in addition to

"For discussions of these problems, see Robert L. Hale, "Bargaining. Duress, and Economic Liberty." Columbia Law Review 43 (1943), 603-28; Betty Mensch "Freedom of Contract as Ideology," Stanford Law Review, 22 (1981), 753-72; and Patrick J. Monahan, "The Supreme Court and the Economy," in Ivan Bernier and Andree Lajoie, eds., The Supreme Court of Canada as an Instrument of Political Change (Toronto 1986), 113-6.

sMail, 25 April 1872.

${ }^{*}$ For example, see the report of a private meeting of Toronto employers to resist the Nine Hours movement in Leader, 19 April 1872 and editorials in the Canadian Illustrated News (Montreal), 13 May 1871, 30 March, and 6 April 1872.

"Leader, 2 April 1872. 


\section{THAT INDEFINITE AREA OF TOLERATION 39}

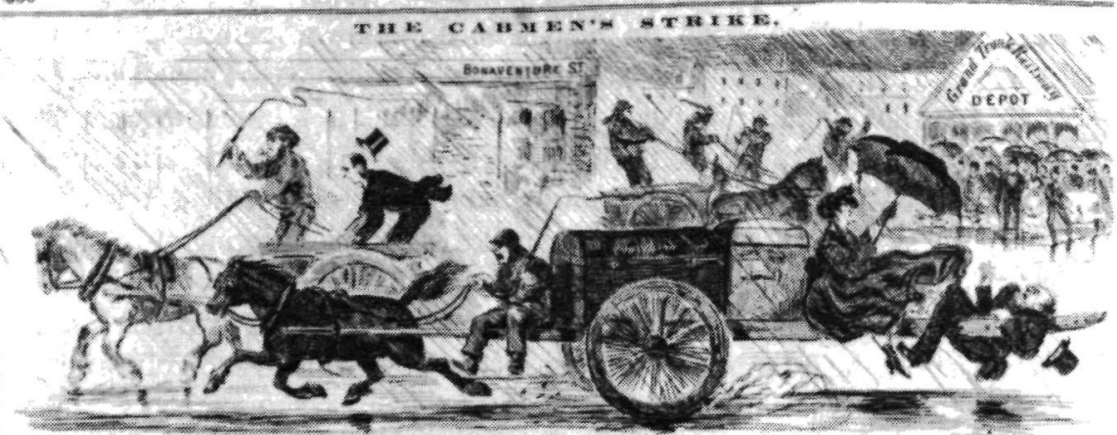

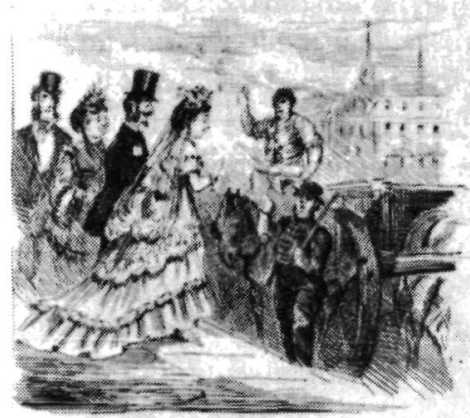

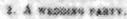
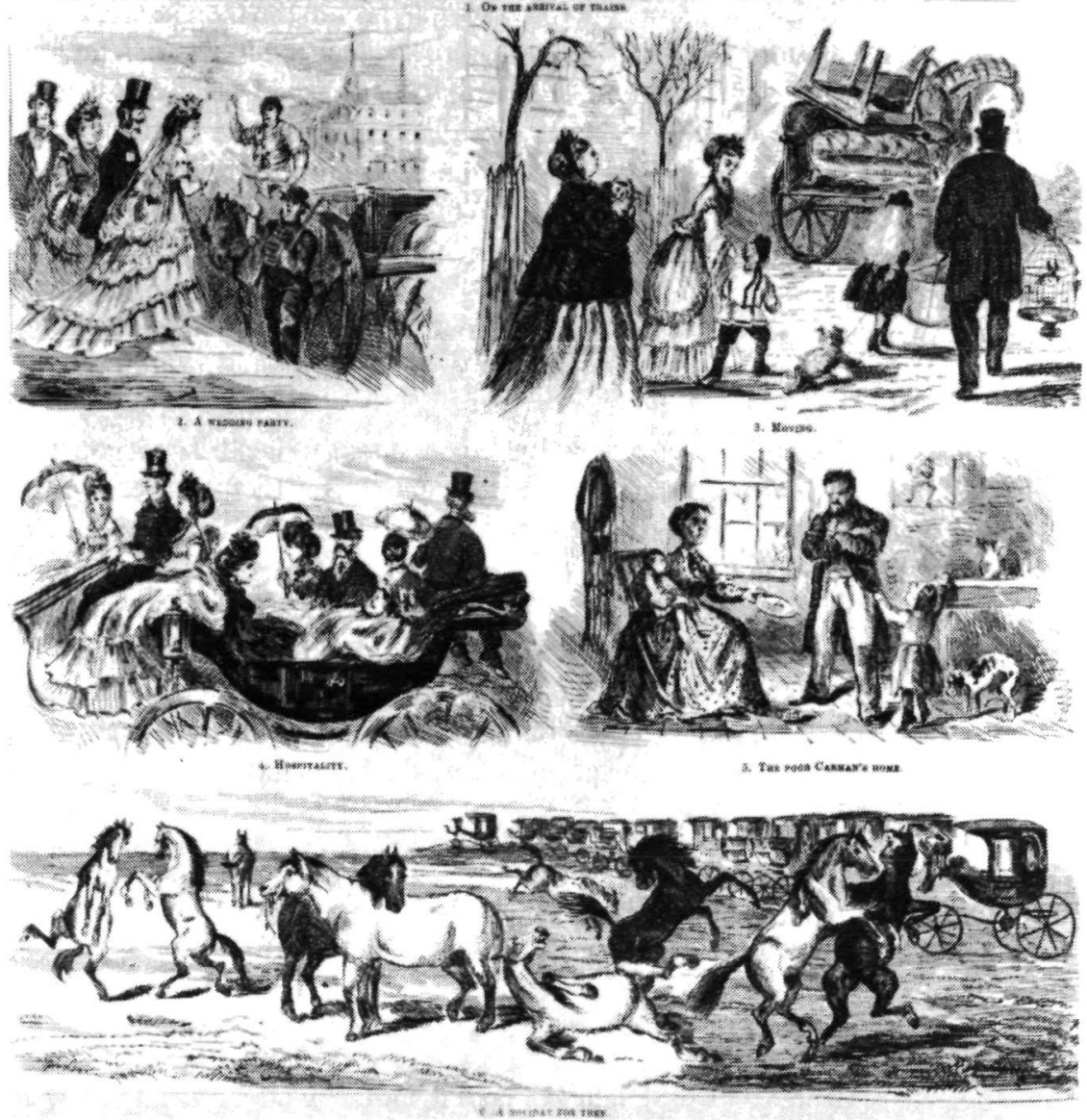

The Cabman's Strike, Canadian Illustrated News, volume 3, 13 May 1871, p.300. (Metropolitan Toronto Library Board.) 
raising wages or shortening hours which, if pursued by a combination, would make it a criminal conspiracy. Second, on the day his opinion was published, Harrison was visited by a deputation of journeymen printers who wanted to know if he would agree, notwithstanding his published opinion, to speak at a public meeting they were organizing at St. Lawrence Hall. Harrison noted that he told the delegation that "what I had written I had written as a lawyer and that if as one of the Representatives of the City I was asked to address a public meeting of my fellow citizens I would do so fearlessly reserving to myself the honest expression of views which I entertain on the question of Political Economy. ${ }^{m a n}$ Third, Harrison assisted Brown in drafting the information to be laid against the printers and, following his opinion, did not just have them charged with conspiracy to shorten hours. Rather, the information included nine more specific charges, relating to the use of threats, intimidation, molestation, and inducement to breach their contracts of employment. In preparing the information, Harrison interviewed Detective O'Neill, whom Brown had hired to gather evidence of the union's use of unlawful means, and who was to be a principal witness in the proceedings. ${ }^{\circ}$ Finally, having reviewed the evidence beforehand, he also probably perceived that it would not support findings of specific acts of wrongdoing. Indeed, Harrison refused to conduct the prosecution, despite Brown's urging, because he "had previously made up [his] mind to leave for Ottawa tonight and [would] not, under any circumstances, agree to prosecute [his] own constituents for crime during a session of Parliament. ${ }^{\text {m91 }}$

In any event, this chain of events brought the matter to a head. The legality of trade unions as such, and not of particular actions undertaken by them, became the focal point of debate and served as the immediate impetus for Macdonald's hasty enactment of the Trade Union Act and the Criminal Law Amendment Act, both of which were modelled on English statutes passed the previous year. ${ }^{22}$ The motives for Macdonald's actions have been discussed thoroughly elsewhere and need only be summarized here. ${ }^{93}$ In the House, Macdonald's stated purpose was to harmonize the law of Canada with that of England so as not to discourage skilled workers from immigrating." As well, it is fair to speculate that the legislation was intended to

"Robert Harrison, Diaries, 30 March 1872, OA, MU 8301-06 (originals), MU 8476-78 (typescript).

${ }^{89}$ See Criminal Assize Indicoments, York County, 1872, OA, RG 22, Series 392, Box 193, J.S. McMillan et al. case file.

${ }^{9}$ Robert Harrison, Diaries, 13 April 1872.

${ }^{91}$ Robert Harrison, Diaries, 17 April 1872.

${ }^{92}$ S.C. 1872, c. 30 and c. 31.

${ }^{93}$ D.G. Creighton, "George Brown, Sir John Macdonald, and the 'Workingman'," Canadian Historical Review, 24 (1943) 362; Ostry, "Conservatives, Liberals"; Mark Chartrand, "The First Canadian Trade Union Legislation: An Historical Perspective," Ontawa Law Review. 16 (1984), 267-96.

Mebates, 7 May 1872. 
secure for the Tories the support of skilled workers and emberrass George Brown, a prominent Grit and an old political enemy of Macdonald. Moreover, the legitimacy of the kegal regime was at stake. As mentioned eartier, it was becoming increasingly difficult to justify glaring differences between the legal treatment of combinations of workers and combinations of employers. In a speech given to a mass meeting of workers called to express their appreciation to the Macdonalds for the legislation, Macdonald explained that Harrison's opinion had drawn his attention to the anomaly of the law and Brown's prosecution had made clear the need to reform it. He went on to say, "Labour and capital should meet precisely upon equal terms, and any law which prevents the employer and the employed from acting in a similar way, or from combining in the same degree and in the same manner, or from standing exactly upon the same footing, occupying the same status and the same platform, is unjust, improper, and should be amended. nes

\section{The Regime of Formal Legal Toleration: 1872-1877}

SECTION 2 OP THE TRADE UNION ACT provided that a member of a trade union could not be prosecuted for criminal conspiracy merely because the purposes of the trade union were in restraint of trade. This grant of limited immunity was the extent of the statutory legalization of trade unions." The Act did nothing to legalize the means which trade unionists could use to pursue the now clearly-legal purpose of combining to raise wages. Indeed, the accompanying Criminal Law Amendment Act arguably did precisely the opposite. It created more statutory crimes which could only be committed in the course of a trade dispute. Under section 1, using violence to persons or property, threatening, intimidating, or molesting (defined as persistent following, hiding tools, or watching and besetting) with a view to coerce masters or workers to leave employment, not to accept employment, not to offer employment, to join or leave a union, or to pay a fine or levy imposed by a union were all defined as criminal conduct for which a person was liable to imprisonment for up to three months. Moreover, persons charged with one of these offences were to be tried before magistrates. When these actions were committed by two or more persons acting in combination, they could be prosecuted for criminal conspiracy which carried heavier penalties, but also had to be tried before a jury.

These newly-defined offences substantially overlapped the existing criminal law which already prohibited violence to the person and property, threatening, and intimidating. Legislators recognized this and tried to resolve the problem of double liability in subsection 1(5) which provided that a person found liable under another

${ }^{95}$ Mail, 12 July 1872.

TUnlike the English Trade Union Act, immunity from prosecution was, strictly speaking, limited to members of trade unions registered under the Act (s. 5). This limitation, however, never had any legal or political consequences, even though few unions ever registered. By registering under the Act, trade unions could also gain protection for union property and funds, but did not gain the right to enforce most agreements. 
Act, or otherwive, for a greater offence was not wo be punished twice for the same offence. It also stipulated that a person could not be punished, on the besis of another Act or otherwise, for restraining trade, unless the means used violated this Act."

Regandless of the formal legal effect of the 1872 legislation on the zone of legal wleration, it quicldy came to be understood as the legislation which legalized trade unions. Moreover, it achieved this result through the language of immunities. This had both practical and symbolic effects. If but for the special immunity granted to them by statute, trade unions were criminal conspiracies, then they faced criminal liability if their actions were determined to be outside the statute." Moreover, a person or body that required an immunity from the "normal" law was easily stigmatized in a world in which the formal legal equality of all subjects was a central tenet of the emerging rule-of-law ideology." This made it easier to justify close regulation of the means used by trade unions in onder to protect the community from these potentially dangerous anomalies in their midst.

Although trade unionists and their leaders generally supported passage of this legislation, they were not particularly pleased with it. Both the Ontario Workman and the Toronto Trades' Assembly (TTA) recognized that the legislation was deficient and, in particular, criticized the Criminal Law Amendment Act as "unnecessarily harsh and oppressive." employers who might use them to suppress what trade unionists viewed as legitimate activity, but it also withheld from trade unions the legitimate and lawful status to which they aspired. The legal image of the trade union as an association prone to criminal behaviour made it easier to characterize the community's interests as being opposed to those pursued by organized labour. For these reasons, the repeal of the Act became an important political objective of the trade union movement in the years following its enactment.

The campaign to repeal or reform the Act has been examined at some length elsewhere, ${ }^{101}$ and so the discussion here will be confined to those events and themes

\footnotetext{
"While this stipulation may have been intended to limit the unlawful means upon which a prosecution of criminal conspirecy could be founded to those specified in ss. 1(1)-(3), Chertrand, "First Cenadien Trede Union Legislation," 279, has pointed out that it would have failed to do so. If a person used means that were not unlawful under the Criminal Law Amendments Act, then the possibility of being found liable twice would not arise and the limitation of s. 1(5) would not epply.

This possibility was exploited in R. v. Gibson (1889), 16 O.R. 704. The beckground to the dispute is discussed in Palmer, Culture in Conflict, 86-8.

"On the ideological sigmificance of immunities in British labour law, see Pox, History and Heritage 161-4. The classic aticulation of this ideology is A.V. Dicey, The Law of the Constitution (Londan 1885).

${ }^{100}$ Ontario Workman, 2 May 1872. Aleo, see Ontario Wortoman, 23 May 1872 and TTA. Minutes, 19 April and 21 May 1872.

${ }^{101}$ See Kealey, Toronto Workers, 142-8 and Ostry, "Conservatives, Liberals," 121-7.
} 
directly releted to the legal and social zones of toleration. The easiest way to make the case for repeal was to show that the Act was being used oppressively. The first opportunity to do so arose in March 1873, just as the TTA's campaign for repeal commenced, when four members of the Knights of St. Crispin (KOSC) in Orillia were charged with a conspiracy in relation 10 a violation of the Act. ${ }^{102}$ Briefly, the stoemakers of Orillia had formed a branch of the KOSC, with the support of at leas one employer, Mr. Fitzgerald, who felt he was paying his workers more than others in the area. After a number of meetings, a uniform bill of wages was drawn up and agreed to by the employers, including Fitzgerald. Shortly thereafter, Firzgerald reneged on the agreement and, as a result, his workmen went on strike. Fitzgerald managed to persuade two other members of the KOSC to take the strikers' pleces. The atrikers then exercised their "perfect right, by persuasion, to beg them nor $\mathrm{D}$ violate their solemn pledge ... and if they were in need we would help them. ${ }^{\text {w100 }}$ Their efforts were unsuccessful, but nonetheless, Firzgerald laid an information before the magistrate, changing four KOSC members with conspiracy and with threatening some of his employees. Eventually all four were scquitted and Firgerald was required to pay all costs incurred in the action. However, in the view of Gilbent McFodries, one the defendants, the Bench had leaned against them in the proceedings. For the Ontario Workman, the prosecution provided a concrete example of the law's potential danger, especially when the interpretation of its open-ended terms was left to 'unprofessional magistrates', at least at first instance. 104

The dominion election of 1874 returned a Liberal government. By the spring of 1874, the labour movement had obcained the support of two MPs for the repeal of the Act: Aemilius Irving, a Reformer from Hamilton, and Thomas Moss, an Independent Liberal from Toronto West. ${ }^{105}$ A Select Committee of Parliament composed of, amongst others, Irving, Moss and Macdonald was struck on 11 May 1874 to examine reform of the Act. It reported eight days later that the object of the 1872 Acts had been to "legalize the combination of workmen, destroy the old doctrines of restraint of Trade, and declare that combinations which had for their object the compulsion of Masters by strike, should no longer be conspiracies." The Commituce acknowledged that the Act contained stringent provisions creating new offences, but attributed worker dissatisfaction to this legislation in Canada and its English model to its judicial construction which had "not operated fairly to the working classes as the respective Legislatures of the two Countries intended in

102 The following socount is derivod from The Expositor (Orillia), 13 and 20 March 1873 , Orillia Packet, 23 March 1873; Ontario Workman, 20 and 27 March 1873. The citation of the Criminal Law Amendments Act in the charge of conspiracy is noted in Ontario Workmam, 27 March 1873.

${ }^{103}$ Orillia Packet, 23 Murch 1873.

${ }^{104}$ Ontario Worbman, 27 March 1873.

${ }^{105}$ Moss, it will be recalled, was Harrison's law partner and allegedly disagreed with his opinion on the legal status of trade unions. 
enacting them." The Committee recommended that Canada await the report of a Royal Commission appointed in England to enquire into the law and its operation. Nevertheless, they concluded by "admitting that the law is unsatisfactory, and that it is capable of being administered oppressively and requires amendment," although "no cases of hardship or oppression in its application in the Dominion" had been brought to their attention.

Irving prepared a bill to repeal the Act which received first reading on 11 February $1875 .^{107}$ In moving second reading, Irving supported his bill on the basis that "it was unfair to working men that they should be specially legislated upon. The effect had been found very odious to them." He also observed, "They [workingmen of Canada] believed they should not be legislated against by any tyrannical class." Moss seconded Irving, and in so doing, condemned the motives of the Tories in enacting the legislation of 1872. "While they were compelled, in obedience to the will of the people, to accede to the legalising of Trades' Unions - while they were compelled to permit working men to unite in a peaceful manner for the promotion of their own interests - they succeeded in passing this severe measure, with the purpose and the knowledge that its presence on the Statute Book would prevent the Trades' Union Act from being of any benefit to the working men." Moss also characterized the provisions of the Criminal Law Amendment Act as dangerously vague and claimed that workers should not be left to the mercy of interpretations by magistrates who, unlike judges of the superior courts, "may have intimate relations with employers." He attributed the absence of Canadian cases of hardship caused by the Act to the unwillingness of employers to enforce its harsh provisions against their employees, but did go on to elaborate on the harm done under it to English workers. Moss conceded that there might be a need to "enact some provisions against a possible abuse of the powers which might be set in action by unions under shelter of the Trades Union Acts" but saw no reason why, in the meantime, working men in Canada "should be subject to this statutory menace and insult."

The Minister of Justice, Fournier, agreed that the current legislation was "of too harsh a character for the circumstances of this country, " but insisted "there were offences which must be reached and punished." He was unwilling to support repeal, but, under Irving's threat to press on with his bill, promised to bring in amending legislation that session. ${ }^{100}$

Three days later, Fournier made good on his promise. The principal changes contained in the Government's bill were the removal of watching and besetting as

${ }^{106}$ Journals of the House of Commons, 19 May 1874.

${ }^{10}$ Bill 9. An Act to repeal "An Act to amend the Criminal Law relating to Violence, Threats and Molestations," 2d Sess., 3rd Parliament, 1875.

${ }^{100}$ Debates, 24 March 1875 . Moss' defence of superior court judges is especially noteworthy, since he himself was appointed to the Bench later in 1875.

${ }^{10}$ Mbid. 
an unlawful means, and a clear statement that prosecution for criminal conspiracy arising out of a trade combination could caly be maintained if the means used were unlawful under this Act. Trade combinations were defined as combinations between masters or workmen for regulating or altering their relations or the way in which they conducted their business. The prohibited means related almost exclusively to those to which a worker combination might resort to achieve its goals vis-a-vis an employer. The bill went through without opposition. ${ }^{110}$

Irving and Moss were unable to convince trade unionists that the government's amendments went far enough. ${ }^{111}$ Charges laid against stonecutters in Toronto arising out of a strike taking place just at the time the amendments received royal assent on 8 April highlighted their concern. John Wilson, a stonecutter, had been suspended from the Toronto Stonecutters' Union for agreeing to wort below the union rate. He subsequently scabbed for an employer named Esecon during a dispute over the rate owed to a man who had completed his apprenticeship. The strike was settled on condition that Esson fire the scabs, including Wilson, and pey the union a twenty-dollar fine for hiring below price. Esson agreed. Wilson then brought charges against two union members, alleging that they had breachod the 1875 Act by coercing Esson to dismiss him. The case was heard before Police Magistrate McNabb who seemed to take the position that coencing an employer to dismiss a worker was sufficient, in and of itself, to make out the charge under the Act. He rejocted the argument made by counsel for the defendants that no offence was committed unless there was intimidation or molestation as defined by the Act. ${ }^{112}$ A number of adjoumments followed until early June, when the case was joined to a new set of charges brought by Wilson after he was dismissed from another job because union stonecutters again refused to work with him. Robert Harrison appeared on behalf of the defendants and argued that in the absence of intimidation. molestation, or obstruction, it was not an offence to refuse to work with another person. MaNabb rejected these arguments, convicted the defendants and sentenced them to fifteen days in jail. ${ }^{113}$ The TTA characterized the decision as one that was "both unlawful and unjust."114 At a protest meeting organized by the TTA and the stonecutters, Alfred Oakley, a leader of the stonecutters, denounced McNabb as an imbecile and the law as a disgrace to the country. Others used the conviction as evidence of the urgent need to repeal the amended Criminal Law Amendment Act. ${ }^{115}$

${ }^{110}$ S.C. 1875, c. 39. In the debates, Macolonald claimed credit for legalizing trade unions in 1872 and justified the Criminal Law Amendments Act as necessary at the time because of opposition to reforms that went further than those in England. Debates, 1 April 1875.

${ }^{111}$ TTA, Minutes, 7, 22 April 1875.

${ }^{112}$ Globe, 6 May 1875.

${ }^{113}$ Globe, 4 June 1875.

${ }^{114}$ TTA, Minutes, 16 June 1872.

${ }^{115}$ Mail, 21 Jume 1875. 
The case was appealed and the convicted workers were released on bail. The appeal was heard on 6 July 1875 . Thomas Moss represented the appellants before Mr. Justice Wilson, who ordered the men released forthwith on the grounds that the conviction was "illegal under the Act."116 Still, the practical dangers of the law had been demonstrated and pressure for repeal intensified.

At the following session of Parliament, Edward Blake introduced a government measure based on the English reforms of 1875. One of the most interesting differences between this bill and the existing law was that it was written in class-neutral language. All references to the terms "masters" or "workmen" were removed from the Act. Indeed, the purposes in relation to which the enumerated means were made unlawful were no longer explicitly defined in language specific to labour disputes. Rather, the bill generally applied in relation to actions taken "with a view to compel any other person to abstain from doing anything which he had a legal right to do, or to do anything from which he had a legal right to abstain." A second notable change was that the bill reintroduced "watching and besetting" as an unlawful means, but excluded informational picketing from its definition. Finally, on second reading, Blake, presumably after being lobbied by organized labour, sought leave to introduce an amendment to the definition of intimidation which had been copied from the English Act. This amendment more narrowly defined intimidation as "threats of using violence" to person or property. ${ }^{117}$ In defending this change from objections raised by Macdonald and John Hillyard Cameron that he was going too far, Blake stated, "He entirely agreed with them as to the importance of preserving to the minority of any trade or occupation its liberties against an improper assertion of the so-called rights of the union majority, and he would always be ready while he sat in this House to sustain any legislation that time might determine to be necessary for that purpose. ${ }^{.118}$ The Tories did not press their opposition and the bill passed. ${ }^{119}$

Although labour would have still preferred repeal, they felt satisfied with the results of their intervention into the political process. True, they still faced special legislation, but it was now more narrowly drafted. Informational picketing was permitted and intimidation had to involve the threat of violence. Moreover, in the four years which had passed since the enactment of the Criminal Law Amendment Act in 1872, employers had rarely prosecuted workers under its terms, even during strikes. It had not proven to be the coercive instrument that trade unionists had feared. Concem, therefore, became more focused on the symbolic dimensions of the law. By rewriting the legislation in class-neutral language, workers were no longer singled out as a potentially criminal element in the community in need of

\footnotetext{
${ }^{116}$ Globe, 7 July 1875.

${ }^{117}$ Debates, 7 March 1876.

${ }^{118}$ Debates, 14 March 1876.

${ }^{119}$ An Act to amend the Criminal Law relating to Violence, Threats and Molestation, S.C. 1876, c. 37.
} 
discipline. The law did not tarmish the respectability of workers and their organizations.

By 1876, the trade union movement was already beading into a steep decline as a result of a downturn in the economy. This was reflected organizationally by the demise of the Canadian Labour Union and the TTA, as well as by the lower incidence of strikes in the following years. However, the Brotherhood of Locomotive Engineers' strike against the Grand Trunk in 1876-77 was a notable exception to this pattern, and provides an opportunity to see how employers used the law as it then existed. Remember, that in addition to the Act of 1876, employees could be prosecuted under the general criminal law and master and servant law, while railway workers were also liable to be prosecuted under special laws which made it an offence for them wilfully or negligently to contravene bylaws, orders or regulations lawfully made by their employer where it resulted in danger to life and property. ${ }^{100}$

The events of the strike have been described in detail elsewhere, ${ }^{121}$ and so, again, the focus here will be on the role of the criminal law and on reflections on the zone of toleration generated by the strike. In many rowns, police were used to maintain order and limit efforts by the strikers and their supporters to prevent the trains from running, and in Belleville the militia was called out. Yet as a general matter, little force was used and few arrests were made. Indeed, data on only four arrests in Ontario have been found to date, and in none of these cases were charges laid under the parts of the criminal law directly related to trade disputes. ${ }^{122}$

A more common response was to use the law as a means of warning strikers that they had reached the limit of official toleration. In Straford, for example, the mayor, police magistrate, and local crown attomey met with the strikers and "told them in very simple but firm language the consequences that would inevitably follow, if they in any way interfered with the efforts of the officials to run the trains, drawing their special attention to the penal clauses of the General Railway Act,

${ }^{120}$ On the origins of this regime, see Paul Craven, "The Meaning of Misadventure: The Baptiste Creek Railway Disaster of 1854 and its Aftermath," in Hall et al, eds., Patterns, $108-29$.

${ }^{121}$ See Desmond Morton, "Taking on the Grand Trunk Railway," LabourlLe Travail, 2 (1977), 5-34. For lengthy newspaper accounts, see Globe, 1,2,3, and 4 January 1877 and the Mail, 1,23, and 4 January 1877.

${ }^{122}$ In Toronto John Eaton, secretary of the Brotherhood was arrested after an altercation with John Kay, a non-striking driver. According to one account, (Maih, 1 January 1877), Kay drew a pistol and snapped it in Eaton's face. Eaton knocked him down, breaking his arm. Eaton went to obtain a warrant for Kay's arrest, but was himself arrested, along with another man named Johnson, and charged with assault with intent to kill. In Belleville, a striking worker named William Poole was arrested by the militia for attempting to disable one of the engines. Weekly Intelligencer (Belleville), 5 Janury 1877. In Port Hope, Mr. Kennedy, a Grand Trunk fireman, was arrestod and charged with maliciously attempting to injure an engine. Guide (Port Hope), 4 January 1877. 
which provides a punishment of five years in the Penitentiary for such offences." nid Similarly, after a locomotive was attacked in Point Edward, the mayor and local crown attomey met with the strikers and explained to them that by stopping trains and intimidating drivers "they were arraying themselves against law and order, and no matter what it cost the country, or how many men were required, proceedings of that nature would be put down." ${ }^{\text {12 }}$ As well, the law of riots and the penalties for breaking it were explained. No further problems were encountered.

A number of factors influenced the decisions of the Grand Trunk Railway and local law enforcement officials with respect to the use of the criminal law. First, the strike was atypical both in terms of the number of workers involved and their dispersion in many communities. Officials probably believed that under these circumstances, it was not feasible to make mass arrests and conduct mass trials, especially where there was a measure of community support for the striking workers. For example, the local crown attorney in Stratford explained that prudence kept him from arresting the leaders of the disturbance because the townspeople seemed to be strongly in sympathy with the strikers. ${ }^{125}$ Also, as Sir John A. Macdonald pointed out later that year during debates on a bill to reform the master and servant laws, "The country could not imprison a whole army of men." Moreover, he noted that to arrest a few would only create martyrs whose families would, in any event, be supported by the union. ${ }^{126}$

Heavy use of the criminal law, and especially the Criminal Law Amendment Act and conspiracy charges, not only risked alienating public opinion, but could also harden union resistance and create another issue which had to be resolved to end the strike, especially because in most circumstances, the cases would not have gone to trial when the parties were ready to setule. In the Grand Trunk strike, of those arrested, only William Kennedy was tried before it was settled, and in this case the magistrate reportedly remarked that because "the Company were inclined to deal leniently with Kennedy and on account of insufficiency of the evidence, and the fact that no damage was done," he was imposing a nominal fine of five dollars. ${ }^{127}$ When the strike was settled on 4 January, one of the terms was that all charges against employees would be dropped, unless they were guilty of actual personal violence or destruction of property. That day, Eaton and Johnson were released on $\$ 1,000$-bail. They later appeared in police court and were discharged when the complainant failed to appear. Similarly, when Poole was brought before the magistrate for trial in Belleville, Mr. Bell, solicitor for the GTR, appeared and

${ }^{123}$ Carada, Parliament, "Correspondence Respecting Disturbance on the Line of the Grand Trunk Railway, January 1st., 1877" No. 55 in Sessional Papers (1877), 34-5.

${ }^{224}$ Canada, Parliament, "Correspondence," 32.

${ }^{125}$ Canada, Parliament, "Correspondence," 34.

${ }^{126}$ Debases, 27 March 1877.

${ }^{127}$ Guide (Port Hope), 4 January 1877.

122 Mail, 4 and 12 January 1877. 
informod Mr. Colemen, the county attorney, that he did not want the case to be prouecuted Coleman objected but the magistrate dismissed the case because the witnesses had departed. ${ }^{10}$

For all these reasons, the criminal law was not used as an instrument of repression. Of course, bcal police and the militia were called upon to maintain public order and to protect Grand Trunk Railway property. As well, striking wotkers were made aware of the legal limits within which they could operate, and were wamed that their failure to observe these would result in the use of force. In that sense, the criminal law was used to define the limits of the official zone of toleration, even if it was not strictly enforced.

The atrike also brought to the surface differences in the social zone of toleration. For some, the mere fact of workers acting in concert was viewed as intolerable coexcion, although no physical force was used. For example, the Cobourg Sentinel commented: "There are certain principles, however, which undertie the movement, and one of the most obvious of these is that the managers should not submit to any coercion by such combinations of wortmen... ${ }^{130}$ For others, the limit was reached when trade unionists interfered with the freedom of non-striking wotkers. This view was expressed by Robert Harrison, by then a judge, in his charge to the grand jury at the Hamilton winter assizes of 1877 . His comments were reprinted in newspapers in a number of towns affected by the strike.

As regands strikee, there would always be fights between capital and labour. This was much to be deplored. In this country we are all proud of our permonal liberty, and this does not mean merely the liberty of moving about, but the liberty of thought and opinion. No man in this country is a slave, but every men is bound to fulfill the [legal] contract he hes entered into. No man nood work at a lower rate than that which he has bargained for, but no man should intefere with another who chooses to do so. A man has a perfect right to strike if he chooses, but he has no right under the influence of a trade organization to use violence and prevent others. ${ }^{131}$

The disruptive effects of strikes on third parties was also raised as a concern. By interfering with the ability of the employer to replace striking workers, operations might come to a halt, thereby harming "thousands of business men, and involv[ing] the country in financial disorder from which it would take months to

${ }^{120}$ Cande, Parliement, "Correspondence." 38.

${ }^{130}$ Cobourg Sentinel, 6 Jemuary 1877 . In a similer vein, the Mail, 2 January 1877, disdainfully noted, "The men had simply made up their mind to force the Company to comply with their wishes."

${ }^{131}$ Globe, 8 January 1877. Harrison clipped the Globe's report and pasted it in his diary. He indicated that the word 'legal' should have preceded 'contract'. Robert Harrison, Diaries, 8 Jenuary 1877. His comments were re-printed in the Strafford Beacom, $19 \mathrm{January} 1877$ and the Guide (Port Hope), 11 Janumy 1877. Similar views were expressed in the Brockville Recorder, 11 Jenumy 1877 and the Weekty Intelligencer (Belleville), 5 January 1877. 
recover. ${ }^{\text {n132 }}$ As well, the stoppage of the mails was seen by others to be an intolerable result. ${ }^{133}$

Finally, there was nearly universal condemnation of the use of force. The Weekly Intelligencer in Belleville, site of the most violent confrontations, denounced the strikers in the strongest terms. "The action and conduct of the men has been of the most heartless character, and should, be met with the severest penalties of the law. Not only did they stop work themselves, but they by force prevent others from taking their places, and commit acts which should send them to the Penitentiary. ${ }^{n 13}$ Even those who sympathized with the workers denounced violence. Thus the Brockville Recorder, after criticizing the Grand Trunk, went on to say, "At the same time no arbitrary conduct on the part of the officials can for a moment justify the engineers in resorting to force or the destruction of property. ${ }^{n 135}$ According to another newspaper, the failure promptly to enforce the law had "caused the people to question the supremacy of British law. ${ }^{\text {n236 }}$

The workers themselves, or at least their leaders and public representatives, also recognized limits on the means that could be used to achieve their purposes. For example, they also denounced the use of violence, and in defending themselves in the press asserted the existence of "a strictly-enforced rule that any member who purposely damages the property of a railroad, or wantonly assaults anyone, is dismissed from the Brotherhood." ${ }^{.13}$ They also complained that the law was applied unequally. Strikers were arrested on false charges while non-strikers were not being arrested no matter what offences they committed. However, they also believed that they had the right to exercise their collective economic power to promote their self-interest, and that they could picket and employ other peaceful means to persuade other workers not to take their places.

The repeal of the master and servant acts later that year completed this wave of legal reform and provided another opportunity to debate the meaning of the Grand Trunk Railway strike and the limits of legitimate union activity. In an important sense, the law reproduced for the individual contract of employment the same duality which characterized the legal articulation of the zone of toleration for trade unions and their activities. On the one hand, there was to be formal legal equality between workers and employers while, on the other, workers needed to be subject to the discipline of special criminal laws punishing their misconduct. The first objective was achieved by repealing the legislation in force in Ontario and Quebec which criminalized all breaches of employment contracts by workers while

\footnotetext{
${ }^{132}$ Brockville Recorder, 11 January 1877.

${ }^{133}$ Canadian Illustrated News, 20 January 1877.

${ }^{134}$ Weekly Intelligencer (Belleville), 5 Jamuary 1877.

${ }^{135}$ Brockville Recorder, 11 January 1872.

${ }^{136}$ Daily Planet (Belleville), 4 January 1877.

${ }^{137}$ Mail, 1 January 1877.
} 
leaving employer breaches to be treated as civil wrongs. ${ }^{13}$ By 1877 , it was more difficult, although not totally out of the question, to defend this difference by openly referring to the social reality of capitalism: employers, as propertied people, could answer for their breaches in damages, while the only property workers had to answer with was their bodies. ${ }^{139}$ The second objective was realized by criminalizing wilful and malicious breaches of contract where a person knew oc had reasonable cause to believe that his or her action, alone or in combination with others, would result in certain harms. These included endangerment of human life, damage to property, interference with the supply of gas or water, and delay in the operation of the railways. Of course, like the 1876 legislation, the Act was written in class neutral language so that on its face any person could commit a criminal breach of contract, but the class to which it was addressed was clear.

Critics objected to the law's unequal treatment of labour and capital, calling it "class legislation," and asserted that "the sooner the House got out of the idea that it could make good servants by making people criminals, the sooner they would be able to reach proper legislation. " 1100 As well, there were those who objected that the bill did not go far enough to suppress strikes. ${ }^{\text {Ml }}$ Blake insistod, however, that the bill was consistent with earlier legislation in that it did not interfere with the rights of workers to combine and to strike, provided they acted peacefully. Its purpose was not to protect the employer from economic loss, but to safeguard the public against serious harm. ${ }^{142}$

\section{Conclusion}

BY THE LATB 1870S, it no longer was possible to treat worker combinations as criminal conspiracies. Aside from the sheer difficulty of repressing trade unions, the ideological premises of liberalism and its increasingly important social role in legitimating a capitalist social formation made such a position less tenable. Notions about freedom of contract and association supported the legalization of workers joining together to promote their self-interest, while belief in the juridical equality of individuals made it more difficult to openly treat propertyless workers differently from their propertied employers. These principles were too fundamental not to be applied to workers without prejudicing the legal regime's legitimacy. The creation of a legal zone of toleration was, in this limited sense, imperative and, consequently,

\footnotetext{
${ }^{132}$ The Breaches of Contract Act, 1877, S.C. 1877 , c. 35.

${ }^{139}$ On the earlier use of this justification, see Craven, "Master and Servant." Such an argument was made in defence of the Breaches of Contract Act by Mr. Brooks. See Debates, 20 March 1877.

${ }^{140}$ Charles Tupper (Cumberland) declared that "class legislation was to be deplored, unless it was found to be absolutely necessary." David Blain is the speaker quoted. Generally, see comments of Irving, Blain, and Tupper in Debates, 20 and 27 March 1877.

${ }^{141}$ In particular, see the comments of Mr. Rochester. Debates, 27 March 1877.

${ }^{142}$ Debates, 20 March 1877.
} 


\section{LABOUR/LE TRAVAIL}

largely uncontested. However, the terms upon which industrial legality was to be constructed were the object of struggle.

The common law of criminal conspiracy and the criminal law statutes enacted between 1872 and 1877 formally defined those terms and thus became a terrain of contest. While it is likely that the common law courts eventually would have accepted the bare legality of trade unions, it was the legislative branch of government which acturally performed this task. However, the legislature narrowly defined the formal kgal zone of toleration. Workers, unlike their propertied employers, could not just withhold their individual labour power from production in order to drive up its price. They had to prevent other workers from taking their jobs and to keep their employers from putting their property into production without them. They interfered with other individuals' right to trade. To do so, they used a variety of means, ranging from peaceful picketing to physical interference with persons and property. Sometimes public order and convenience might be disturbed. The object, after all, was to disrupt the production and distribution of goods and services. Because of this, it was easy to cast the trade union as a body whose interests were in conflict with those of the public, and whose activities, therefore, had to be restricted. Moreover, because of the differences in the respective positions of labour and capital, it usually was possible for the criminal law to achieve this result while maintaining the appearance of formal legal equality. Masters did not watch and beset, workers did. Thus, although the struggle for formal legal equality was an important one, its achievement in criminal law yielded only limited benefits. For workers, formal equality was not true equality. ${ }^{143}$

It is important to recall, however, that the common law of criminal conspiracy and the criminal law amendments after 1872 rarely were used in Ontario during the period studied. It would seem inappropiiate, therefore, to characterize this branch of the law as an instrument of coercion. Rather, its greatest effects probably were ideological. More work needs to be done before firm conclusions can be drawn, but some tentative hypotheses might be explored. Clearly, the skilled workers who dominated the trade union movement aspired to respectability. The denial of legal status to their organizations was an affront to their dignity, but did not cause them to change their beliefs about the legitimacy of their associational life. Similarly, these workers resented their legal identification as a class in need of discipline. Although skilled workers did not generally endorse violence, especially against people, they were prepared, at times, to exert some level of force to protect their jobs when employers brought in replacements. It is not clear from this

${ }^{143}$ See Claus Offe and Hebmut Wiesenthal, "Two Logics of Collective Action: Theoretical Notes of Social Clase and Orgenizational Form." Political Power and Social Theory, 1 (1980), 67-115. The unequal treatment of labour and capital in civil law was more persistent. For a diecussion of how this problem was negotinted in the United States, see Herbert Hoventsmp, "Labor Conspiracies in American Law, 1880-1930," Texas Law Review, 66 (1988), 919-65. 
study that the law tempered workers' beliefs about the limits of legitimate activity where these differed from the legally defined limits. However, it is likely that trade union leaders were more concerned about the strict legality of strike activity than were the members.

The greatest ideological effect of the law was probably not on unionized workers, but on other sectors of public opinion. That is, it helped to create or reinforce a division between workers and their communities by building images of unions as bodies whose activities needed to be carefully monitored. The legal image of the union as a narrow interest group, whose members were prone to violence and disorder, and whose activities might disnupt the economic wellbeing of society by interfering with the production of wealth, helped to create a political and social environment which limited the ability of trade unionists to attract broeder support for their cause.

Finally, the contours of industrial legality which began to emerge in the $1870 \mathrm{~s}$ established a pattern that can still be seen in the legal terms upon which trade unions today are incorporated into capitalist industrial relations. The legal right to form trade unions is entrenched for most workers, but their activities, including the right to strike, are narrowly circumscribed. ${ }^{144}$ More recently, this restrictive pattern of legal incorporation has found expression in Cansdisan constitutional law in the 1980s. The Supreme Court of Canada has held that under the Charter of Rights and Freedoms, there is a constitutionally protected zone of toleration which extends to the right of workers to form trade unions, but it does not include the right to pursue the goals of their association. In perticular, there is no constitutional right to strike nor to bargain collectively. Furthermore, although peaceful picketing is constitutionally protected as free speech, the court has been sympathetic to arguments that limitations on picketing are demonstrably justified in a free and democratic society. ${ }^{145}$ This articulation of the constitutional framework of labour law not only supports the status quo of the 1980 s, but also parallels the laws of the 1870 s which immunized workers from criminal prosecutions for forming trade unions and restricted them in the pursuit of their objectives.

In sum, there has not been a linear progression from repression or restriction towards toleration, legal or social. Rather, restraint has been a condition of toleration both in law and for many sectors of a class-divided capitalist social order. Workers contested the zone of legal toleration with some limited success, but as a

${ }^{14}$ See Geoff England, "Some Observations on Selected Strike Laws," in Kenmeth P. Swan and Katherine E. Swinton, eds., Studies in Labour Law, (Toronto 1983), 240-96. For more recent developments, see Leo Panitch and Donald Swart, The Assault on Trade Union Freedoms (Toronto 1988).

${ }^{145}$ For discussion of the relevant cases, see Judy Fudge, "Labour, the New Constitution and Old Style Liberalism," in Bernard Adell, ed., Labour Law Under the Charter (Kingston 1988), 61 and HJ. Glasbeek, "Contempt for Workers," Osgoode Hall Law Journal, 28 (1990), 1-52. 


\section{LABOUR/LE TRAVAIL}

general matter have been unable to overcome the narrowly defined limits on legitimate trade union activity. From the start, the legal terms of incorporation into capitalism were not favourable.

I would like to thank Judy Fudge, Harry Glasbeek, Reuben Hasson, Doug Hay, participants in the Legal History Seminar at the University of Toronto and the Labour Studies Research Group, and the three anonymous Labour/Le Travail reviewers for their comments on an earlier version of this article. I am particularly indebted to Bryan Palmer for generously sharing with me some of his unpublished research.

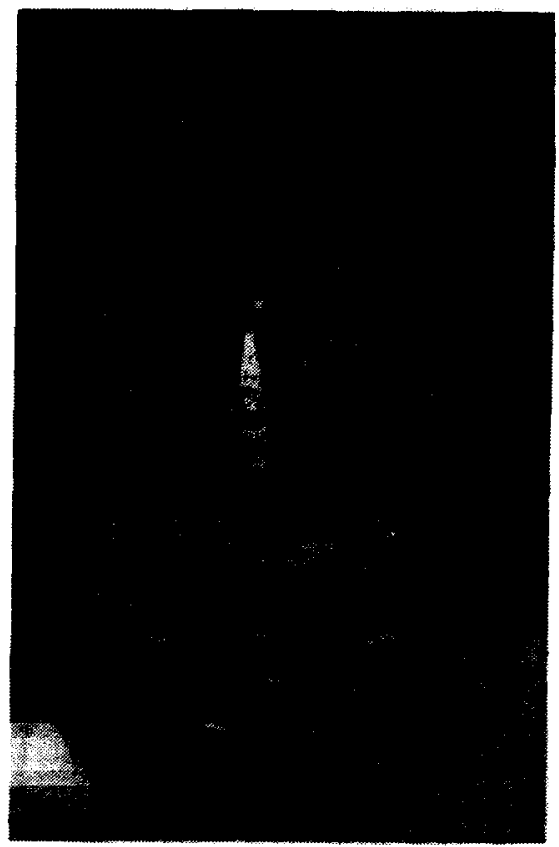

CORPORATE CANADA:

An Historical Outline

Gerry van Houten,

Progress Publishers, 1991

This book, written from a Marxist perspec tive, outline's how Canada's economy has been shaped from the earliest days of the fur trade to the latest efforts by corporate interests to bring about free trade.

\section{$\$ 19.95$ With GST: \$21.34}

To order: Please add \$1/- for shipping and handling charges and mail to:

Progress Books, 72 Tecumseth Street,

Toronto, Ontario M5V 2R8

Phone: (416) 368-5336

Fax: (416) 363-3623 